\title{
ONION PLANT GROWTH AND YIELD AS AFFECTED BY NITROGEN, POTASSIUM AND SULPHUR COMBINATIONS UNDER EL-ARISH REGION CONDITIONS
}

\author{
Ayatullah E. El-Morsy ${ }^{*}$, A.A.I. El-Kassas ${ }^{1}$ and E.M. El-Tantawy ${ }^{1}$
}

1. Plant Prod. Dept., Fac. Environ. Agric. Sci., Arish Univ., Egypt

\begin{abstract}
A field experiment was carried out at The Experimental Farm of Fac. Environ. Agric. Sci., Arish University, North Sinai, Egypt, during the winter seasons of 2014-2015 and 2015-2016 to study the effect of different combinations among nitrogen, potassium and sulphur levels on growth, yield, and pungency of onion (Allium cepa L.) cv. "White Sweet Spanish" compared to control (recommended doses of N, K and S). The results indicated that application of $150 \%$ $\mathrm{N}+75 \% \mathrm{~K}_{2} \mathrm{O}+200 \% \mathrm{~S}$ of recommended dose was the best treatment wherein increased fresh weight of leaves, bulbs and total fresh weight as well as the dry weight of the same previous parameters and photosynthetic pigments in the $1^{\text {st }}$ season. Concerning yield and its components, application of $150 \% \mathrm{~N}+75 \% \mathrm{~K}_{2} \mathrm{O}+200 \% \mathrm{~S}$ was the best treatment for increasing the total yield and its components compared to the recommendation treatment and the other treatments. The previous treatment recorded increases of total relative yield by $131.42 \%$ and $115.77 \%$ in $1^{\text {st }}$ and $2^{\text {nd }}$ seasons, respectively compared to control treatment (recommended dose); increment in marketable yield by $130.95 \%$ and $112.08 \%$ in $1^{\text {st }}$ and $2^{\text {nd }}$ seasons, respectively; increase in relative yield of both $1^{\text {st }}$ and $2^{\text {nd }}$ grades which increased by $131.04 \%$, $115.22 \%$ for the $1^{\text {st }}$ grade in both seasons, respectively, and by 127.89 and $111.77 \%$ for the sum of $1^{\text {st }}+2^{\text {nd }}$ grades in the $1^{\text {st }}$ and $2^{\text {nd }}$ seasons, respectively, while application of $150 \% \mathrm{~N}+$ $75 \% \mathrm{~K}_{2} \mathrm{O}+100 \% \mathrm{~S}$ recorded the lowest value of bulb pungency.
\end{abstract}

Key words: Onion, nitrogen, potassium, sulphur and yield.

\section{INTRODUCTION}

Onion (Allium cepa L.) is one of the important vegetable crops in Egypt, and used both in the raw and mature bulb stages as a vegetable and spice. The area cultivated in Egypt in 2015 was 192.000 fed. which produced 2.889 million ton with average of 15.5 ton/fed. (Minist. Agric., Egypt, 2016 Dept. Agric. Static.). It is the member of the genus Allium of the family Alliaceae. Nitrogen is an essential constituent of various enzymes. The protein content of vegetative plant organs as well as storage tissue may be influenced by $\mathrm{N}$ supply. It conceders the principal plant nutrient required in much greater quantities, the level of $\mathrm{N}$ that should be applied to a crop depends largely on particular crop species and on the prevalent soil conditions. In general, for poor soils which are low in $\mathrm{N}$, the $\mathrm{N}$ application rate should be in excesses of the total amount of $\mathrm{N}$ uptake.

Un sufficient nitrogen supply may make shortage in plant growth in earlier stage.

This early senescens probably relates to the effect of the $\mathrm{N}$ supply on the synthesis and translocation of cytokinins. Many efforts studied the effect of $\mathrm{N}$ on onion plant growth, dry weight, photosynthetic pigments (Khan et al., 2002; Al-Fraihat, 2009; El-Tantawy and El-Beik, 2009; 
Rizk, Fatma et al., 2012; Kolota et al., 2013; Simon et al., 2014; Biru, 2015; ElSagan and Abd EI Baset; 2015; Gessesew et al., 2015). Abd El-Kader et al. (2007) found that application of $\mathrm{N}$ increased pungency in onion bulbs with application up to $100 \mathrm{~kg} \mathrm{Nfed}^{-1}$., and it decreased with high amount of $\mathrm{N}\left(120 \mathrm{~kg} \mathrm{Nfed}^{-1}\right)$.

Potassium is one of three major nutrients taken up by plant in large quantities, among the major nutrients, potassium plays a vital role in plant metabolism such as photosynthesis, translocation of photosynthetic substrates, regulation of plant pores, activation of plant catalysts and resistance against pests and diseases. It is also considered as a quality element as it improves quality parameters of many crops including onion. Potassium improves color, glossiness and dry matter accumulation besides improving bulb quality of onion. Application of $\mathrm{K}$ resulted in increments in onion plant growth and yield as recorded by El-Bassiony (2006), Islam et al. (2008), Siddiquee et al. (2008), Verma and Singh (2012), Shafeek et al. (2013) and Behairy et al. (2015).

Sulphur has a direct effect on soil properties which greatly decreased $\mathrm{pH}$ values. The positive effect of sulphur on reducing soil $\mathrm{pH}$ values may be attributed to the oxidation of sulphur to sulphoric acid by many species of soil microorganisms. The decrease of soil $\mathrm{pH}$ improves the availability of microelements such as $\mathrm{Fe}$, $\mathrm{Zn}, \mathrm{Mn}$, and $\mathrm{Cu}$ and improves the chemical properties of sandy soil, as well as it conceders the fourth major plant nutrient after nitrogen, phosphorus and potassium in crops. It is a constituent of sulphur containing amino acids (cysteine and methionine), which are building blocks for essential proteins in the plant (Mengel and Kirkby, 1978). Moreover, it is essential for a good vegetative growth and bulb development in onion and it has a strong influence on onion flavor and pungency through involvement in the volatile $\mathrm{S}$ compounds.

Onion is an important sulphur-loving crop and it is required for proper growth and yield of onion. Sulphur has been found not only to increase the bulb yield but also it improves its quality especially flavors and pungency. Sulphur containing secondary compounds is of importance for nutritive value and flavors as well as for resistance against pests and diseases and consequently increased plant growth and yield (Kil et al., 2006; Al-Fraihat, 2009; El-Tantawy and El-Beik, 2009; Lee et al., 2009; Rizk, Fatma et al., 2012; Mishu et al., 2013; de Souza et al., 2015). So, this work aimed to study the effect of $\mathrm{N}, \mathrm{K}$, and $\mathrm{S}$ in different combinations on productivity and quality of onion (Allium cepa L.) cv. White Sweet Spanish under El Arish region conditions.

\section{MATERIALS AND METHODS}

A field experiment was carried out at The Experimental Farm of Fac. Environ. Agric. Sci., Arish Univ., North Sinai, Egypt, during the winter seasons of 2014-2015 and 2015-2016. The main object of this work was to study the effect of nitrogen, potassium and sulphur combinations on growth, yield, and pungency of onion (Allium cepa $\mathrm{L}$.) $\mathrm{cv}$. "White Sweet Spanish".

White Sweet Spanish' produces a large and globed shaped white onion. A medium to fair storage onion. Onions are mild, sweet and have a white skin. Soil received $30 \mathrm{~m}^{3}$ compost (Table 1c).

Plants were transplanted on $24^{\text {th }}$ February in both seasons. Drip irrigation system was used. Double dripper lines were used, the distance between the centers of the double dripper lines was $75 \mathrm{~cm}$ and 20 $\mathrm{cm}$ between the two dripper lines in each double dripper line. The transplants were transplanted in one row on each side of the dripper line at $10 \mathrm{~cm}$ between plants in the 
SINAI Journal of Applied Sciences (ISSN: 2314-6079) Vol. (5) Is. (3), Dec. 2016

Table (1a.): The physical and chemical properties of the experimental soil*

\begin{tabular}{lcc}
\hline Property & $\begin{array}{c}\mathbf{1}^{\text {st }} \text { season } \\
(\mathbf{2 0 1 4 / 2 0 1 5 )}\end{array}$ & $\begin{array}{c}\mathbf{2}^{\text {nd }} \text { season } \\
(\mathbf{2 0 1 5 / 2 0 1 6})\end{array}$ \\
\hline Physical properties & sandy & sandy \\
Texture & & \\
Chemical properties & 7.8 & 7.9 \\
pH & 1.3 & 0.98 \\
EC $\left(\mathrm{dSm}^{-1}\right)$ & 16.22 & 15.83 \\
Total N (ppm) & 0.33 & 0.34 \\
Total P (ppm) & 0.79 & 0.63 \\
Total K (ppm) & &
\end{tabular}

* Soil samples were taken from the $25 \mathrm{~cm}$ of the soil surface.

Table (1b): The physical and chemical analyses of irrigation water

\begin{tabular}{|c|c|c|c|c|c|c|c|c|c|}
\hline \multirow{3}{*}{ pH } & \multirow{3}{*}{$\begin{array}{c}\mathbf{E C} \\
(\mathrm{ppm})\end{array}$} & \multicolumn{8}{|c|}{ Soluble ions (meq.. $\mathrm{L}^{-1}$ ) } \\
\hline & & \multicolumn{5}{|c|}{ Cations } & \multicolumn{3}{|c|}{ Anions } \\
\hline & & $\mathrm{Mg}^{-1}$ & $\mathrm{Ca}^{++}$ & $\mathrm{Mg}^{++}$ & $\mathrm{Na}^{+}$ & $\mathrm{K}^{+}$ & $\mathrm{Cl}^{-}$ & $\mathrm{HCO}_{3}{ }^{-}$ & $\mathrm{SO}_{4}^{-{ }^{-1}}$ \\
\hline 7.03 & 3513 & 4499 & 16.33 & 17.60 & 35.87 & 0.27 & 42.26 & 6.13 & 21.41 \\
\hline
\end{tabular}

Table (1c): Analysis of organic fertilizer compost for both seasons.

\begin{tabular}{cc}
\hline $\begin{array}{c}\text { Organic fertilization } \\
\text { Content }\end{array}$ & Values \\
\hline OM (\%) & 36.56 \\
pH (1:10) & 8.6 \\
Total N (\%) & 1.24 \\
Total P (\%) & 0.58 \\
Total K (\%) & 1.15 \\
Organic Carbon (\%) & 20.84 \\
$\mathrm{C} / \mathrm{N}$ ratio & $1: 16.8$ \\
$\mathrm{Fe}(\%)$ & 1.26 \\
$\mathrm{Mn} \mathrm{(ppm)}$ & 578 \\
$\mathrm{Cu}(\mathrm{ppm})$ & 136 \\
$\mathrm{Zn} \mathrm{(ppm)}$ & 130 \\
\hline
\end{tabular}

Source: Center Laboratory of Organic Agriculture, Agric. Res. Center, Ministry of Agriculture. 
same row. All Sulphur, and one third of nitrogen, were added to the soil during the soil preparation, while the other two thirds of $\mathrm{N}$, and all doses of $\mathrm{P}$ and $\mathrm{K}$ were divided into 28 doses which were added two times weekly beginning 15 days after transplanting. $\mathrm{N}, \mathrm{P}$ and $\mathrm{K}$ were added as ammonium sulphate, phosphoric acid and potassium sulphate, respectively.

\section{Soil and Water Analysis}

Mechanical and chemical analyses for the experimental soil as well as, analysis of irrigation water are tabulated in Tables 1a and $1 b$.

The study included nine treatments as follows:

$1.100 \%$ of recommended nitrogen dose (130 kg N added as $\mathrm{NH}_{3} \mathrm{SO}_{4}$ ) $+100 \%$ of $\mathrm{K}_{2} \mathrm{O}\left(150 \mathrm{~kg} \mathrm{~K}_{2} \mathrm{O}\right.$ added as $\left.\mathrm{K}_{2} \mathrm{SO}_{4}\right)+$ $100 \%$ of Sulphur $(200 \mathrm{~kg} \mathrm{~S})$ as the control treatment),

$2.75 \%$ of recommended $\mathrm{N}$ dose $+75 \%$ of $\mathrm{K}_{2} \mathrm{O}+100 \% \mathrm{~S}$,

$3.75 \%$ of recommended $\mathrm{N}$ dose $+75 \%$ of $\mathrm{K}_{2} \mathrm{O}+200 \% \mathrm{~S}$,

$4.75 \%$ of recommended $\mathrm{N}$ dose $+150 \%$ $\mathrm{K}_{2} \mathrm{O}+100 \% \mathrm{~S}$,

$5.75 \%$ of recommended $\mathrm{N}$ dose $+150 \%$ of $\mathrm{K}_{2} \mathrm{O}+200 \% \mathrm{~S}$,

$6.150 \%$ of recommended $\mathrm{N}$ dose $+75 \%$ of $\mathrm{K}_{2} \mathrm{O}+100 \% \mathrm{~S}$,

$7.150 \%$ of recommended $\mathrm{N}$ dose $+75 \%$ of $\mathrm{K}_{2} \mathrm{O}+200 \% \mathrm{~S}$,

$8.150 \%$ of recommended $\mathrm{N}$ dose $+150 \%$ of $\mathrm{K}_{2} \mathrm{O}+100 \% \mathrm{~S}$, and

$9.150 \%$ of recommended $\mathrm{N}$ dose $+150 \%$ of $\mathrm{K}_{2} \mathrm{O}+200 \% \mathrm{~S}$.

These Nine treatments were randomly arranged in a randomized complete block design, with three replicates.

\section{Data Recorded}

\section{Vegetative growth parameters}

Samples of 3 plants of each replicate were randomly taken at 45 and 75 days after transplanting to study the vegetative growth of plants. Plant height $(\mathrm{cm})$, number of leaves/plant, leaf area $\left(\mathrm{cm}^{2}\right) /$ plant (which was calculated according Ackley, 1964), leafe fresh weight/plant (g), bulb fresh weight/ plant (g), root fresh weight/plant $(\mathrm{g})$, and total fresh weight/plant (g) were determined.

\section{Dry weight}

The plant samples were oven dried at $70^{\circ} \mathrm{C}$ until the constant weight and the dry weights of root, bulb and leaves were used for calculating the total dry weight. The following traits were estimated: Leaf dry weight/plant (g), bulb dry weight/plant (g), root dry weight/plant $(\mathrm{g})$, and total dry weight/ plant (g).

\section{Photosynthetic pigments content (mg/g fresh weight)}

Disks from 10 mature fresh leaves per plant were taken from each experimental unit, washed with distilled water to remove any residue, then, chlorophyll $\mathrm{A}, \mathrm{B}$ and Carotene contents were determined as $\mathrm{mg} / \mathrm{g}$ fresh weight using the method of Wettestein (1957).

\section{Yield and its components}

Plants were harvested when $50 \%$ of leaves bent. Bulbs were weighed after curing and the following data were recorded: Grading: It was determined according to the specification of Ministry of Agriculture and Soil Reclamation for Onion Exportation (1963).

- Marketable yield of bulbs (ton fed. ${ }^{-1}$ ): weight of grade $1+$ grade $2+$ grade 3 ,

- Unmarketable yield of bulbs (ton fed. ${ }^{-1}$ ): weight of grade4+ rotted bulbs + decay bulbs.

- Total yield (ton fed. ${ }^{-1}$ ). It included the marketable yield fed $^{-1}$. +unmarketable yield fed $^{-1}$

- First grade as $\%$ of total yield: (weight of $1^{\text {st }}$ grad / total yield) X100 
- Bulb average weight of $1^{\text {st }}$ grade: weight of $1^{\text {st }}$ grade/ number of bulbs of $1^{\text {st }}$ grad,

- Second grade as (\%) of total yield: (weight of $2^{\text {nd }} \mathrm{grad} /$ total yield tonfed. $\left.^{-1}\right) \times 100$.

- Bulb average weight of $2^{\text {nd }}$ grade: weight of $2^{\text {nd }}$ grade/ number of bulbs of $2^{\text {nd }}$ grad.

- $1^{\text {st }}$ and Second grad as (\%) of total yield: (weight of $1^{\text {st }}+2^{\text {nd }}$ grades)/ total yield (ton fed. ${ }^{-1}$ ) X100.

- Bulb average weight of $3^{\text {rd }}$ grade: weight of $3^{\text {rd }}$ grade/ number of bulbs of $3^{\text {rd }}$ grad.

- Bulb average weight of $4^{\text {th }}$ grade: weight of $4^{\text {th }}$ grade/ number of bulbs of $4^{\text {th }}$ grad.

- Rotted as (\%) of total yield: (weight of rotted/total yield ton fed. $\left.{ }^{-1}\right) \mathrm{X} 100$.

- Bulb average weight: total weight of bulbs/ total number of bulbs.

\section{Pungency analysis (pyruvic acid)}

It was determined by using the method of Schwimmer and Weston (1961).

\section{Statistical Analysis}

The obtained data were subjected to statistical analysis of variance according to Snedecor and Cochran (1980), and means separation was done according to Duncan's multiple range test (1955).

\section{RESULTS AND DISCUSSION}

\section{Effect of Treatments on Plant Growth}

\section{Plant height, number of leaves, and leaf area}

Results in Table 2 show significant effects for the combinations among N, K, and $\mathrm{S}$ on some vegetative growth traits of onion; viz, number of leaves/plant, plant height, and leaf area/plant. The highest plant height was recorded with application of $150 \% \mathrm{~N}+75 \% \mathrm{~K}_{2} \mathrm{O}+200 \% \mathrm{~S}$ at 45 days after transplanting in both seasons, without significant differences with application of $150 \% \mathrm{~N}+150 \% \mathrm{~K}_{2} \mathrm{O}+200 \% \mathrm{~S}$ which recorded the highest plant height at 75 days after transplanting.

The same data show a slight significant differences among the treatments on number of leaves/plant, wherein application of high amount of nutrients increased plant height followed by the treatment of recommendation dose (control treatment). Concerning leaf area/plant the same data illustrate that application of $150 \% \mathrm{~N}+75 \%$ $\mathrm{K}_{2} \mathrm{O}+200 \% \mathrm{~S}$ was the best treatment for increasing leaf area/plant at 45 and 75 day of transplanting in both seasons without significant difference with application of $150 \% \mathrm{~N}+150 \% \mathrm{~K}_{2} \mathrm{O}+200 \% \mathrm{~S}$ at 75 days in $1^{\text {st }}$ season.

\section{Plant fresh weight}

Data presented in Table 3 illustrate that fertilizing onion plant with $150 \% \mathrm{~N}+75 \%$ $\mathrm{K}_{2} \mathrm{O}+200 \% \mathrm{~S}$ of recommended dose significantly increased fresh weight of leaves at the both periods of plant growth (45 and 75 days DAT) in both seasons without significant difference with application of $150 \% \mathrm{~N}+150 \% \mathrm{~K}_{2} \mathrm{O}+200 \% \mathrm{~S}$ of the recommended dose at 75 days in the $1^{\text {st }}$ season.

Regarding fresh weight of bulbs, data revealed that the same previous treatment for fresh weight was true for bulb fresh weight in the $1^{\text {st }}$ season without significant differences between application of $150 \% \mathrm{~N}+$ $150 \% \mathrm{~K}_{2} \mathrm{O}+200 \% \mathrm{~S}$. In the $2^{\text {nd }}$ season, the superior treatment for the same parameter was $75 \% \mathrm{~N}+150 \% \mathrm{~K}_{2} \mathrm{O}+200 \% \mathrm{~S}$ at 45 and 75 DAT without significant difference than application of $150 \% \mathrm{~N}+150 \% \mathrm{~K}_{2} \mathrm{O}+100 \%$ $\mathrm{S}$ at 45 DAT. On the same trend, application of $150 \% \mathrm{~N}+75 \% \mathrm{~K}_{2} \mathrm{O}+200 \%$ $\mathrm{S}$ was the best treatment which achieved the highest fresh weight of roots in the $1^{\text {st }}$ season, while application of $75 \% \mathrm{~N}+150 \%$ $\mathrm{K}_{2} \mathrm{O}+100 \% \mathrm{~S}$ increased fresh weight of roots at 45 and 75 DAT without significant differences than application of $75 \% \mathrm{~N}+$ $75 \% \mathrm{~K}_{2} \mathrm{O}+200 \% \mathrm{~S}$ or with $150 \% \mathrm{~N}+75 \%$ $\mathrm{K}_{2} \mathrm{O}+100 \% \mathrm{~S}$ at 45 DAT. 
Table (2):Effect of $N, K$ and $S$ treatments on plant height, number of leaves, and leaf area/plant in 2014/2015 and 2015/ 2016 seasons.

\begin{tabular}{|c|c|c|c|c|c|c|}
\hline \multirow[t]{3}{*}{ Treatments } & \multicolumn{2}{|c|}{ Plant height (cm) } & \multicolumn{2}{|c|}{ Number of leaves/plant } & \multicolumn{2}{|c|}{ Leaf area/plant $\left(\mathrm{cm}^{2}\right)$} \\
\hline & \multicolumn{6}{|c|}{ Days after transplanting } \\
\hline & 45 & 75 & 45 & 75 & 45 & 75 \\
\hline & \multicolumn{6}{|c|}{ First season (2014/2015) } \\
\hline $100 \% \mathrm{~N}+100 \% \mathrm{~K}_{2} \mathrm{O}+100 \% \mathrm{~S}$ & $47.33 \mathrm{c}$ & $76.78 \mathrm{ab}$ & $6.111 \mathrm{ab}$ & $10.44 \mathrm{a}$ & $209.4 \mathrm{c}$ & $878.8 \mathrm{abc}$ \\
\hline $75 \% \mathrm{~N}+75 \% \mathrm{~K}_{2} \mathrm{O}+100 \% \mathrm{~S}$ & $45.44 \mathrm{~d}$ & $70.22 \mathrm{~d}$ & $6.000 \mathrm{abc}$ & $9.445 \mathrm{bc}$ & $209.5 \mathrm{c}$ & $746.5 \mathrm{de}$ \\
\hline $75 \% \mathrm{~N}+75 \% \mathrm{~K}_{2} \mathrm{O}+200 \% \mathrm{~S}$ & $36.89 \mathrm{~g}$ & $63.89 \mathrm{e}$ & $5.556 \mathrm{c}$ & $9.222 \mathrm{c}$ & $176.7 \mathrm{~d}$ & $618.7 \mathrm{f}$ \\
\hline $75 \% \mathrm{~N}+150 \% \mathrm{~K}_{2} \mathrm{O}+100 \% \mathrm{~S}$ & $44.22 \mathrm{e}$ & $75.11 \mathrm{bc}$ & $6.444 \mathrm{a}$ & $9.555 \mathrm{abc}$ & $238.2 \mathrm{~b}$ & $800.8 \mathrm{~cd}$ \\
\hline $75 \% \mathrm{~N}+150 \% \mathrm{~K}_{2} \mathrm{O}+200 \% \mathrm{~S}$ & $43.44 \mathrm{e}$ & $70.89 \mathrm{~d}$ & $5.667 \mathrm{bc}$ & $9.111 \mathrm{c}$ & $217.7 \mathrm{c}$ & $689.1 \mathrm{ef}$ \\
\hline $150 \% \mathrm{~N}+75 \% \mathrm{~K}_{2} \mathrm{O}+100 \% \mathrm{~S}$ & $47.00 \mathrm{c}$ & $76.89 \mathrm{ab}$ & $6.222 \mathrm{a}$ & $9.445 \mathrm{bc}$ & $251.0 \mathrm{~b}$ & $840.9 \mathrm{bcd}$ \\
\hline $150 \% \mathrm{~N}+75 \% \mathrm{~K}_{2} \mathrm{O}+200 \% \mathrm{~S}$ & $57.44 \mathrm{a}$ & $78.44 \mathrm{ab}$ & $6.333 \mathrm{a}$ & $10.00 \mathrm{abc}$ & $277.0 \mathrm{a}$ & $925.8 \mathrm{ab}$ \\
\hline $150 \% \mathrm{~N}+150 \% \mathrm{~K}_{2} \mathrm{O}+100 \% \mathrm{~S}$ & $41.11 \mathrm{f}$ & $77.56 \mathrm{ab}$ & $6.333 \mathrm{a}$ & $9.555 \mathrm{abc}$ & $184.2 \mathrm{~d}$ & $817.8 \mathrm{~cd}$ \\
\hline \multirow[t]{2}{*}{$150 \% \mathrm{~N}+150 \% \mathrm{~K}_{2} \mathrm{O}+200 \% \mathrm{~S}$} & $51.00 \mathrm{~b}$ & $79.11 \mathrm{a}$ & $6.445 \mathrm{a}$ & $10.33 \mathrm{ab}$ & $214.4 \mathrm{c}$ & $968.2 \mathrm{a}$ \\
\hline & \multicolumn{6}{|c|}{ Second Season $(2015 / 2016)$} \\
\hline $100 \% \mathrm{~N}+100 \% \mathrm{~K}_{2} \mathrm{O}+100 \% \mathrm{~S}$ & $50.22 \mathrm{bc}$ & $79.33 \mathrm{ab}$ & $6.444 \mathrm{ab}$ & $9.556 \mathrm{a}$ & 264.2 bc & $1023 \mathrm{~b}$ \\
\hline $75 \% \mathrm{~N}+75 \% \mathrm{~K}_{2} \mathrm{O}+100 \% \mathrm{~S}$ & $48.00 \mathrm{~d}$ & $75.00 \mathrm{c}$ & $5.889 \mathrm{c}$ & $9.222 \mathrm{ab}$ & $187.6 \mathrm{e}$ & $864.8 \mathrm{de}$ \\
\hline $75 \% \mathrm{~N}+75 \% \mathrm{~K}_{2} \mathrm{O}+200 \% \mathrm{~S}$ & $50.67 \mathrm{bc}$ & $79.22 \mathrm{a}$ & $6.556 \mathrm{a}$ & $8.778 \mathrm{bc}$ & $239.6 \mathrm{~cd}$ & $960.3 \mathrm{bcd}$ \\
\hline $75 \% \mathrm{~N}+150 \% \mathrm{~K}_{2} \mathrm{O}+100 \% \mathrm{~S}$ & $49.78 \mathrm{~cd}$ & $75.44 \mathrm{bc}$ & $6.333 \mathrm{abc}$ & $9.000 \mathrm{abc}$ & $224.8 \mathrm{~d}$ & 909.0 cde \\
\hline $75 \% \mathrm{~N}+150 \% \mathrm{~K}_{2} \mathrm{O}+200 \% \mathrm{~S}$ & $50.33 \mathrm{bc}$ & $76.11 \mathrm{bc}$ & $6.000 \mathrm{bc}$ & $8.556 \mathrm{c}$ & $249.1 \mathrm{~cd}$ & $833.9 \mathrm{e}$ \\
\hline $150 \% \mathrm{~N}+75 \% \mathrm{~K}_{2} \mathrm{O}+100 \% \mathrm{~S}$ & $49.78 \mathrm{~cd}$ & $76.00 \mathrm{bc}$ & $6.000 \mathrm{bc}$ & $8.667 \mathrm{bc}$ & $282.3 \mathrm{~b}$ & 883.7 cde \\
\hline $150 \% \mathrm{~N}+75 \% \mathrm{~K}_{2} \mathrm{O}+200 \% \mathrm{~S}$ & $56.33 \mathrm{a}$ & $82.78 \mathrm{a}$ & $6.556 \mathrm{a}$ & $9.444 \mathrm{a}$ & $327.9 \mathrm{a}$ & $1228 \mathrm{a}$ \\
\hline $150 \% \mathrm{~N}+150 \% \mathrm{~K}_{2} \mathrm{O}+100 \% \mathrm{~S}$ & $48.33 \mathrm{~d}$ & $73.56 \mathrm{c}$ & $5.889 \mathrm{c}$ & $9.444 \mathrm{a}$ & $243.1 \mathrm{~cd}$ & $986.0 \mathrm{bc}$ \\
\hline $150 \% \mathrm{~N}+150 \% \mathrm{~K}_{2} \mathrm{O}+200 \% \mathrm{~S}$ & $51.89 \mathrm{~b}$ & $80.33 \mathrm{a}$ & $6.444 \mathrm{ab}$ & $9.222 \mathrm{ab}$ & $261.0 \mathrm{bc}$ & $913.3 \mathrm{cde}$ \\
\hline
\end{tabular}

Values having the same alphabetical letter(s) did not significantly differ at 0.05 level of significance according to Duncan's multiple range test.

Table (3): Effect of $N$, $K$ and $S$ combination treatments on fresh weight of leaves, bulb, root, and total fresh weight of onion plant.

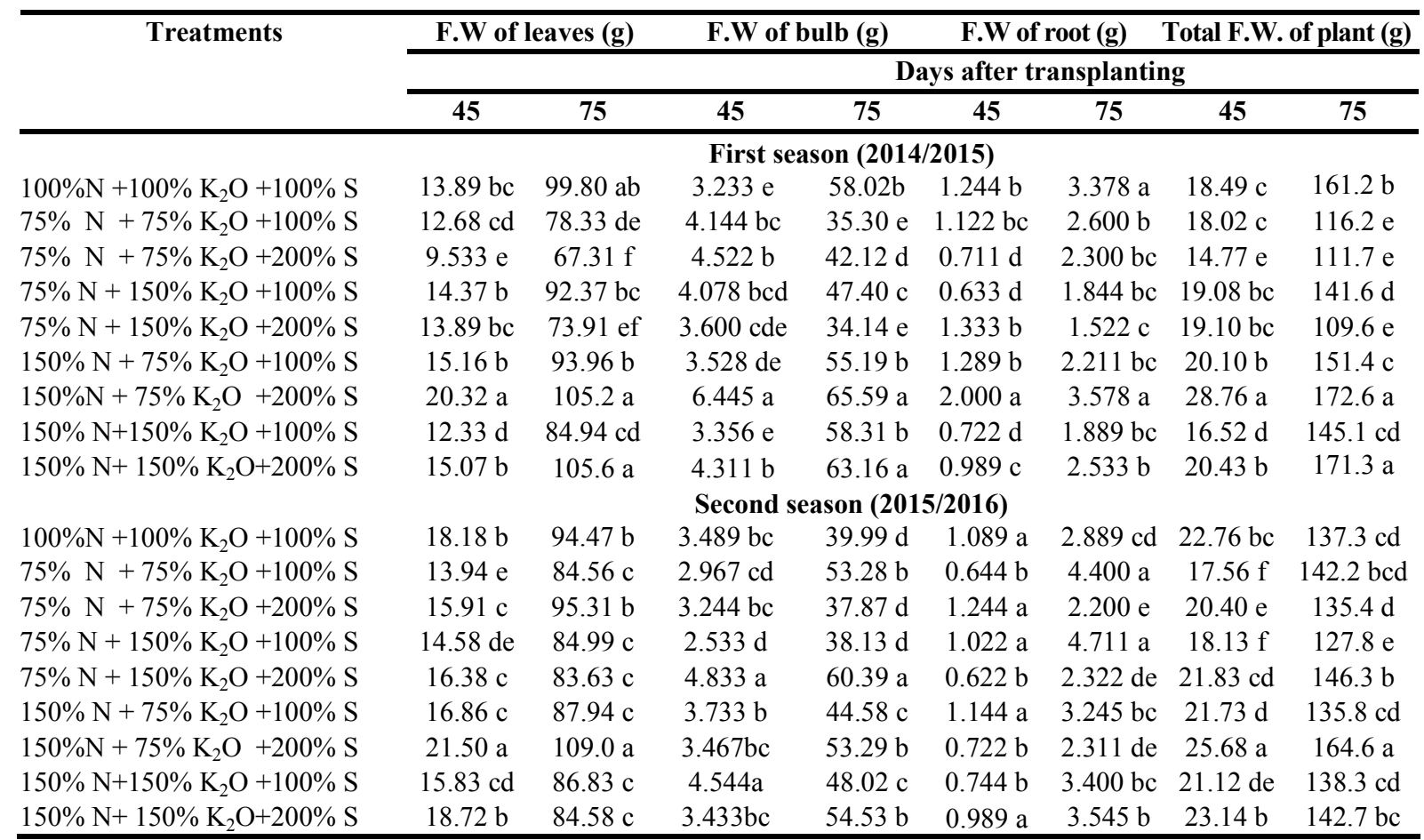

Values having the same alphabetical letter(s) did not significantly differ at 0.05 level of significance according to Duncan's multiple range test. 
Concerning total fresh weight of onion plant, the same results showed that fertilizing with $150 \% \mathrm{~N}+75 \% \mathrm{~K}_{2} \mathrm{O}+$ $200 \% \mathrm{~S}$ was the superior treatment in both seasons.

Generally, it could be concluded that the best treatment for increasing fresh weight of onion plant was the application of $150 \% \mathrm{~N}+$ $75 \% \mathrm{~K}_{2} \mathrm{O}+200 \% \mathrm{~S}$ of recommended dose. The increment in total fresh weight due to the high amounts of $\mathrm{N}$ and $\mathrm{S}$ may be owe to the increments in fresh weight of different plant organs; i.e., fresh weight of leaves, bulbs, and roots. The relative increasing in total fresh weight due to application of the same previous treatment was $155.45 \%$ and $107.07 \%$ in the $1^{\text {st }}$ season at 45 and 75 DAT, respectively and $112.82 \%$ and $119.88 \%$ in the $2^{\text {nd }}$ season at 45 and 75 DAT, respectively. In addition the increment in total fresh weight may be owe directly to the increment in number of leaves and leaf area/plant (Table 2). The increment in plant growth and leaf area as well as fresh weight of onion plant due to application of $150 \% \mathrm{~N}+75 \% \mathrm{~K}_{2} \mathrm{O}+200 \% \mathrm{~S}$ may be owe to application of high dose of $\mathrm{N}$ and $\mathrm{S}$ under sandy soils.

\section{Plant dry weight}

The results in Table 4 show that application of $150 \% \mathrm{~N}+75 \% \mathrm{~K}_{2} \mathrm{O}+200 \% \mathrm{~S}$ has significant effect on dry weight of leaves in both seasons at 45 and 75 DAT without significant differences with application of $150 \% \mathrm{~N}+150 \% \mathrm{~K}_{2} \mathrm{O}+200 \% \mathrm{~S}$ at 75 and 45 DAT in the $1^{\text {st }}$ and $2^{\text {nd }}$ season, respectively. The same previous treatment was the superior treatment for dry weight of bulb in the $1^{\text {st }}$ season, but the treatment of $75 \% \mathrm{~N}+150 \% \mathrm{~K}_{2} \mathrm{O}+200 \% \mathrm{~S}$ was the best one in the $2^{\text {nd }}$ season at 45 and 75 DAT, without significant difference than $150 \% \mathrm{~N}$ $+150 \% \mathrm{~K}_{2} \mathrm{O}+200 \% \mathrm{~S}$ at 45 days and with application of $150 \% \mathrm{~N}+75 \% \mathrm{~K}_{2} \mathrm{O}+200 \% \mathrm{~S}$ or $150 \% \mathrm{~N}+150 \% \mathrm{~K}_{2} \mathrm{O}+200 \% \mathrm{~S}$ at $75 \mathrm{DAT}$.

Concerning dry weight of roots, the same data indicated that, application of
$75 \% \mathrm{~N}+150 \% \mathrm{~K}_{2} \mathrm{O}+100 \% \mathrm{~S}$ increased the dry weight of roots at 45 and 75 DAT in the $1^{\text {st }}$ season without significant difference than recommended dose (control) at 75 days. The same treatment recorded the highest value in the $2^{\text {nd }}$ season at 75 days, while application of $75 \% \mathrm{~N}+75 \% \mathrm{~K}_{2} \mathrm{O}+$ $200 \% \mathrm{~S}$ was the best one at $45 \mathrm{DAT}$.

In addition, total dry weight of onion plant at 45 and 75 DAT in both seasons was significantly increased with application of $150 \% \mathrm{~N}+75 \% \mathrm{~K}_{2} \mathrm{O}+200 \% \mathrm{~S}$. The relative increases in total dry weight compared to control treatment were $122.73 \%$ and $121.50 \%, 114.85 \%$ and $102.77 \%$ in $1^{\text {st }}$ and $2^{\text {nd }}$ seasons at 45 and 75 DAT, respectively. The increment in dry weight of onion plant may be owe to the increment in fresh weight of plant (Table 3 ).

\section{Effect of treatments on onion photosynthetic pigments}

The results in Table 5 reveal that application of $150 \% \mathrm{~N}+75 \% \mathrm{~K}_{2} \mathrm{O}+200 \% \mathrm{~S}$ was the best treatment which increased $\mathrm{Chl}$. a, Chl. b, and caroten at 45 and 75 DAT in the $1^{\text {st }}$ season. On the other hand, the treatments did not have a constant direction in the $2^{\text {nd }}$ season where they fluctuated mainly among the same previous treatments and other treatments. However, it could be said that application of $150 \% \mathrm{~N}+75 \% \mathrm{~K}_{2} \mathrm{O}$ $+200 \% \mathrm{~S}$ increased photo-assimilation pigments of onion plant in the $1^{\text {st }}$ season particularly.

These results may be owed to the roles of $\mathrm{N}$ and $\mathrm{S}$ in assimilation of photosynthetic pigments. In this connection, Kolota et al. (2013) found increments in photosynthetic pigments (chl. $a+b$, and carotene) in onion plants. So, it could be said that, the increment in plant growth expressed in number of leaves/plant, leaf area, both of fresh and dry weight as well as photosynthetic pigments as shown in Tables $2,3,4,5$ due to application of $150 \% \mathrm{~N}+$ $75 \% \mathrm{~K}_{2} \mathrm{O}+200 \% \mathrm{~S}$ may be related to fertilization with high amounts of $\mathrm{N}$ and $\mathrm{S}$ under poor soils (sandy and calcareous soils). 
Table (4): Effect of $N, K$ and $S$ combination treatments on dry weight of leaves, bulb, root, and total dry weight of plant onion.

\begin{tabular}{|c|c|c|c|c|c|c|c|c|}
\hline \multirow[t]{3}{*}{ Treatments } & \multicolumn{2}{|c|}{$\begin{array}{c}\text { D.W of leaves } \\
(\mathrm{g})\end{array}$} & \multicolumn{2}{|c|}{$\begin{array}{c}\begin{array}{c}\text { D.W of bulb } \\
(\mathrm{g})\end{array} \\
\end{array}$} & \multicolumn{2}{|c|}{$\begin{array}{c}\text { D.W of root } \\
\text { (g) }\end{array}$} & \multicolumn{2}{|c|}{$\begin{array}{c}\text { Total Dry weight } \\
\text { of plant (g) }\end{array}$} \\
\hline & \multicolumn{8}{|c|}{ Days after transplanting } \\
\hline & 45 & 75 & 45 & 75 & 45 & 75 & 45 & 75 \\
\hline \multicolumn{9}{|c|}{ First season $(2014 / 2015)$} \\
\hline $100 \% \mathrm{~N}+100 \% \mathrm{~K}_{2} \mathrm{O}+100 \% \mathrm{~S}$ & $1.368 \mathrm{~b}$ & $7.533 \mathrm{~cd}$ & $.2557 \mathrm{~h}$ & $56 \mathrm{bc}$ & $2677 \mathrm{~b}$ & $0.6223 \mathrm{a}$ & $1.891 \mathrm{~b}$ & $12.51 \mathrm{bc}$ \\
\hline $75 \% \mathrm{~N}+75 \%$ & $1.054 \mathrm{~d}$ & $6.100 \mathrm{ef}$ & $0.3823 \mathrm{~b}$ & 00 de & $0.2043 \mathrm{~g}$ & $0.4300 \mathrm{abc}$ & & $630 \mathrm{~d}$ \\
\hline $75 \% \mathrm{~N}+75 \% \mathrm{~K}_{2} \mathrm{O}+$ & $0.835 \mathrm{e}$ & $5.155 \mathrm{f}$ & $0.2723 \mathrm{~g}$ & $3.611 \mathrm{~cd}$ & $0.1580 \mathrm{~h}$ & $0.3123 \mathrm{bc}$ & $1.265 \mathrm{~d}$ & $9.079 \mathrm{~d}$ \\
\hline $75 \% \mathrm{~N}+1$ & $1.267 \mathrm{bc}$ & $6.922 \mathrm{de}$ & $567 \mathrm{~d}$ & $3.867 \mathrm{bcd}$ & $0.3073 \mathrm{a}$ & $0.5057 \mathrm{ab}$ & $1.931 \mathrm{~b}$ & $11.29 \mathrm{c}$ \\
\hline $75 \% \mathrm{~N}+1$ & $1.110 \mathrm{~cd}$ & $9.944 \mathrm{~b}$ & $0.3143 \mathrm{e}$ & & $0.2313 \mathrm{~d}$ & $223 \mathrm{c}$ & & $11.13 \mathrm{c}$ \\
\hline $150 \% \mathrm{~N}+75 \% \mathrm{~K}_{2} \mathrm{O}$ & $1.431 \mathrm{~b}$ & $7.533 \mathrm{~cd}$ & $0.2810 \mathrm{f}$ & $4.478 \mathrm{~b}$ & $0.2067 \mathrm{f}$ & $0.3267 \mathrm{bc}$ & $1.919 \mathrm{~b}$ & $12.34 \mathrm{bc}$ \\
\hline 15( & $1.779 \mathrm{a}$ & $10.55 \mathrm{ab}$ & $077 \mathrm{a}$ & $9 \mathrm{a}$ & $0.1343 \mathrm{i}$ & $0.2857 \mathrm{c}$ & $21 \mathrm{a}$ & $15.20 \mathrm{a}$ \\
\hline & $1.134 \mathrm{~cd}$ & $00 \mathrm{c}$ & $857 \mathrm{f}$ & $2 \mathrm{bc}$ & 87 e & 733 c & $9 \mathrm{c}$ & $13.10 \mathrm{~b}$ \\
\hline $150 \% \mathrm{~N}$ & $1.364 \mathrm{~b}$ & $11.33 \mathrm{a}$ & $0.3737 \mathrm{c}$ & $3.600 \mathrm{~cd}$ & $\mathrm{c}$ & $0.3357 \mathrm{bc}$ & $1.994 \mathrm{~b}$ & $15.27 \mathrm{a}$ \\
\hline \multicolumn{9}{|c|}{ Second season $(2015 / 2016)$} \\
\hline 100 & & $8.111 \mathrm{~d}$ & $3123 \mathrm{~b}$ & $4.533 \mathrm{~b}$ & $0.2280 \mathrm{~b}$ & $867 \mathrm{c}$ & $7 \mathrm{~cd}$ & $15.11 \mathrm{a}$ \\
\hline $75 \% \mathrm{~N}$ & & & $910 \mathrm{~b}$ & & & & & $56 \mathrm{c}$ \\
\hline $75 \% \mathrm{~N}+$ & $\mathrm{b}$ & $1 \mathrm{~b}$ & $190 \mathrm{~b}$ & 87 e & $0.2847 \mathrm{a}$ & $0.2943 \mathrm{i}$ & $2.092 \mathrm{cde}$ & $12.89 \mathrm{e}$ \\
\hline $75 \% \mathrm{~N}+150 \% \mathrm{~K}_{2} \mathrm{O}+$ & $1.516 \mathrm{~b}$ & $6.833 \mathrm{e}$ & $0.2263 \mathrm{c}$ & $3.267 \mathrm{f}$ & $0.2200 \mathrm{c}$ & $0.6567 \mathrm{a}$ & $1.962 \mathrm{e}$ & $10.75 \mathrm{i}$ \\
\hline $0 \% \mathrm{~K}_{2} \mathrm{O}+200 \% \mathrm{~S}$ & $1.444 \mathrm{bc}$ & $5.922 \mathrm{f}$ & $0.4643 \mathrm{a}$ & $5.070 \mathrm{a}$ & $0.1443 \mathrm{i}$ & $0.3557 \mathrm{~g}$ & $2.052 \mathrm{de}$ & $11.34 \mathrm{~g}$ \\
\hline $150 \% \mathrm{~N}+75 \% \mathrm{~K}_{2} \mathrm{O}+100 \% \mathrm{~S}$ & $1.552 \mathrm{~b}$ & $6.833 \mathrm{e}$ & $0.3133 \mathrm{~b}$ & $3.911 \mathrm{~d}$ & $0.2157 \mathrm{~d}$ & $0.3647 \mathrm{f}$ & $2.081 \mathrm{de}$ & $11.11 \mathrm{~h}$ \\
\hline $00 \% \mathrm{~S}$ & $1.928 \mathrm{a}$ & $10.11 \mathrm{a}$ & $0.3033 \mathrm{~b}$ & $4.933 \mathrm{a}$ & $0.2120 \mathrm{e}$ & $0.3200 \mathrm{~h}$ & $2.443 \mathrm{a}$ & $15.53 \mathrm{a}$ \\
\hline $150 \% \mathrm{~N}+150 \% \mathrm{~K}_{2} \mathrm{O}+100 \% \mathrm{~S}$ & $1.566 \mathrm{~b}$ & $7.973 \mathrm{~d}$ & $0.4590 \mathrm{a}$ & $4.222 \mathrm{c}$ & $0.2057 \mathrm{f}$ & $0.4420 \mathrm{~d}$ & $2.230 \mathrm{bc}$ & $12.64 \mathrm{f}$ \\
\hline $150 \% \mathrm{~N}+150 \% \mathrm{~K}_{2} \mathrm{O}+200 \% \mathrm{~S}$ & $1.812 \mathrm{a}$ & $8.589 \mathrm{c}$ & $0.2863 \mathrm{~b}$ & $4.889 \mathrm{a}$ & $0.1957 \mathrm{~g}$ & $0.4100 \mathrm{e}$ & $2.294 \mathrm{~b}$ & $13.89 \mathrm{~d}$ \\
\hline
\end{tabular}

Values having the same alphabetical letter(s) did not significantly differ at 0.05 level of significance according to Duncan's multiple range test.

Table (5): Effect of $\mathrm{N}, \mathrm{K}$ and $\mathrm{S}$ combination treatments on onion photosynthetic pigments.

\begin{tabular}{|c|c|c|c|c|c|c|}
\hline \multirow[t]{3}{*}{ Treatments } & \multicolumn{2}{|c|}{$\begin{array}{c}\text { Chl. a } \\
\text { (mg/g F.W.) }\end{array}$} & \multicolumn{2}{|c|}{$\begin{array}{c}\text { Chl. b } \\
\text { (mg/g F.W.) }\end{array}$} & \multicolumn{2}{|c|}{$\begin{array}{c}\text { Caroten } \\
(\mathrm{mg} / \mathrm{g} \text { F.W. })\end{array}$} \\
\hline & \multicolumn{6}{|c|}{ Days after transplanting } \\
\hline & 45 & 75 & 45 & 75 & 45 & 75 \\
\hline & \multicolumn{6}{|c|}{ First season (20114/2015) } \\
\hline $100 \% \mathrm{~N}+100 \% \mathrm{~K}_{2} \mathrm{O}+100 \% \mathrm{~S}$ & $1.830 \mathrm{f}$ & $1.480 \mathrm{~b}$ & $1.838 \mathrm{c}$ & $1.485 \mathrm{~cd}$ & $1.831 \mathrm{c}$ & $2.062 b c$ \\
\hline $75 \% \mathrm{~N}+75 \% \mathrm{~K}_{2} \mathrm{O}+100 \% \mathrm{~S}$ & $1.940 \mathrm{e}$ & $1.458 b$ & $1.784 \mathrm{c}$ & $1.375 \mathrm{~d}$ & $1.795 \mathrm{~cd}$ & $1.686 \mathrm{e}$ \\
\hline $75 \% \mathrm{~N}+75 \% \mathrm{~K}_{2} \mathrm{O}+200 \% \mathrm{~S}$ & $1.745 \mathrm{f}$ & $1.867 \mathrm{a}$ & $1.66 \mathrm{c}$ & $1.817 \mathrm{ab}$ & $1.618 \mathrm{~d}$ & $1.995 \mathrm{c}$ \\
\hline $75 \% \mathrm{~N}+150 \% \mathrm{~K}_{2} \mathrm{O}+100 \% \mathrm{~S}$ & $2.219 \mathrm{~cd}$ & $1.848 \mathrm{a}$ & $2.281 \mathrm{a}$ & $1.848 \mathrm{ab}$ & $1.975 b c$ & $2.154 b$ \\
\hline $75 \% \mathrm{~N}+150 \% \mathrm{~K}_{2} \mathrm{O}+200 \% \mathrm{~S}$ & $2.164 d$ & $1.578 b$ & $2.245 \mathrm{a}$ & $1.567 \mathrm{c}$ & $1.923 b c$ & $2.034 b c$ \\
\hline $150 \% \mathrm{~N}+75 \% \mathrm{~K}_{2} \mathrm{O}+100 \% \mathrm{~S}$ & $2.338 b$ & $1.790 \mathrm{a}$ & $2.021 \mathrm{~b}$ & $1.754 b$ & $1.942 b c$ & $2.157 \mathrm{~b}$ \\
\hline $150 \% \mathrm{~N}+75 \% \mathrm{~K}_{2} \mathrm{O}+200 \% \mathrm{~S}$ & $2.466 \mathrm{a}$ & $1.786 \mathrm{a}$ & $2.322 \mathrm{a}$ & $1.894 \mathrm{a}$ & $2.352 \mathrm{a}$ & $2.407 \mathrm{a}$ \\
\hline $150 \% \mathrm{~N}+150 \% \mathrm{~K}_{2} \mathrm{O}+100 \% \mathrm{~S}$ & $2.304 \mathrm{bc}$ & $1.598 b$ & $2.166 \mathrm{ab}$ & $1.551 \mathrm{c}$ & $2.060 \mathrm{~b}$ & $1.823 \mathrm{de}$ \\
\hline \multirow[t]{2}{*}{$150 \% \mathrm{~N}+150 \% \mathrm{~K}_{2} \mathrm{O}+200 \% \mathrm{~S}$} & $2.254 \mathrm{bcd}$ & $1.561 b$ & $2.220 \mathrm{a}$ & $1.543 \mathrm{c}$ & $1.987 \mathrm{bc}$ & $1.847 \mathrm{~d}$ \\
\hline & \multicolumn{6}{|c|}{ Second season $(20115 / 2016)$} \\
\hline $100 \% \mathrm{~N}+100 \% \mathrm{~K}_{2} \mathrm{O}+100 \% \mathrm{~S}$ & $1.924 b c$ & $2.423 a$ & $1.654 \mathrm{~d}$ & $1.852 \mathrm{c}$ & $1.750 \mathrm{bc}$ & $2.196 \mathrm{a}$ \\
\hline $75 \% \mathrm{~N}+75 \% \mathrm{~K}_{2} \mathrm{O}+100 \% \mathrm{~S}$ & $1.653 d$ & $1.962 b$ & $2.016 \mathrm{ab}$ & $2.013 b$ & $1.772 b$ & $2.311 \mathrm{a}$ \\
\hline $75 \% \mathrm{~N}+75 \% \mathrm{~K}_{2} \mathrm{O}+200 \% \mathrm{~S}$ & $2.015 b c$ & $1.800 \mathrm{bcd}$ & $1.720 \mathrm{~d}$ & $1.680 \mathrm{c}$ & $1.958 \mathrm{a}$ & $2.026 b$ \\
\hline $75 \% \mathrm{~N}+150 \% \mathrm{~K}_{2} \mathrm{O}+100 \% \mathrm{~S}$ & $1.860 \mathrm{c}$ & $1.776 \mathrm{~cd}$ & $1.941 b c$ & $1.799 \mathrm{c}$ & $1.630 \mathrm{c}$ & $1.871 \mathrm{bc}$ \\
\hline $75 \% \mathrm{~N}+150 \% \mathrm{~K}_{2} \mathrm{O}+200 \% \mathrm{~S}$ & $1.977 \mathrm{bc}$ & $1.748 \mathrm{~d}$ & $1.94 b c$ & $1.792 \mathrm{c}$ & $1.883 \mathrm{ab}$ & $2.031 b$ \\
\hline $150 \% \mathrm{~N}+75 \% \mathrm{~K}_{2} \mathrm{O}+100 \% \mathrm{~S}$ & $1.619 \mathrm{~d}$ & $2.024 \mathrm{ab}$ & $1.641 d$ & $1.928 \mathrm{c}$ & $1.625 \mathrm{c}$ & $2.229 \mathrm{a}$ \\
\hline $150 \% \mathrm{~N}+75 \% \mathrm{~K}_{2} \mathrm{O}+200 \% \mathrm{~S}$ & $2.333 \mathrm{a}$ & $2.200 \mathrm{ab}$ & $2.140 \mathrm{a}$ & $2.462 \mathrm{a}$ & $1.839 \mathrm{ab}$ & $1.771 \mathrm{c}$ \\
\hline $150 \% \mathrm{~N}+150 \% \mathrm{~K}_{2} \mathrm{O}+100 \% \mathrm{~S}$ & $2.105 b$ & $2.032 \mathrm{ab}$ & $2.102 \mathrm{a}$ & $2.237 \mathrm{~b}$ & $1.801 b$ & $2.019 b$ \\
\hline $150 \% \mathrm{~N}+150 \% \mathrm{~K}_{2} \mathrm{O}+200 \% \mathrm{~S}$ & $2.428 \mathrm{a}$ & $2.222 \mathrm{ab}$ & $1.863 \mathrm{c}$ & $1.858 \mathrm{c}$ & $1.805 \mathrm{~b}$ & $1.910 \mathrm{bc}$ \\
\hline
\end{tabular}

Values having the same alphabetical letter(s) did not significantly differ at 0.05 level of significance according to Duncan's multiple range test. 
It is well known that nitrogen has a vital factor in plants grown in alkaline soils which have high $\mathrm{pH}$. Total amount of $\mathrm{N}$ and its availability related to soil environment such as soil $\mathrm{pH}$. Under alkaline or calcareous soils, nitrogen converted from $\mathrm{NH}_{4}$ to $\mathrm{NO}_{3}$ through nitrification process by soil bacteria and is most rapid in soil and moves freely with soil water. So, soil $\mathrm{pH}$ is very important to increase the availability and use efficiency of nitrogen and other nutrients. Under these conditions, application of sulphur has a benefit role which greatly decreased $\mathrm{pH}$ values (Abd El-Kader et al., 2007) through oxidation of sulphur to sulphoric acide by micro-organisms. Khafagi and Abd ElHadi (1990) and El-Eweddy et al. (2005) who added that EC values of soil was clearly decreased as affected by sulphur application rates.

Adding sulphur to soil had a favorable effect on reducing soil $\mathrm{pH}$, and increasing the availability of certain plant nutrients in the soil (El-Galla et al., 1989).

The obtained results due to application of high rate of $\mathrm{S}\left(150 \mathrm{~kg} \mathrm{~K}_{2} \mathrm{Ofed}^{-1}\right.$.) are in coincide with those reported by Shafeek $\boldsymbol{e t}$ al. (2013) who found that the highest onion plant growth values were recorded with application of $300 \mathrm{Kg} \mathrm{S} \mathrm{Fed}^{-1}$. Also results are in accordance with those of Abd El-Aal et al. (2005), El-Bassiony (2006) and ElDesuki et al. (2006).

Sulphur has a positive effect on reducing soil salinity that may be due to an increment in the solubility of ions as a result of $\mathrm{S}$ oxidation to sulphuric acid. Therefore, more soluble salts may be laced out and move with free soil water. The decrease of soil $\mathrm{pH}$ improves the availability of microelements as Fe, $\mathrm{Zn}, \mathrm{Mn}$ and $\mathrm{Cu}$ (Hetter, 1985) and improve the chemical properties of alkaline soil. Nitrogen had a pronounce role in plant metabolism. It's a constituent of proteins, enzymes, hormones, vitamins, chlorophyll (Reddy and Reddi, 2002) and leaf area/ plant (Table 1) leading to high rate of photo-assimilation and consequently increases in plant growth expressed in fresh and dry weight of plant.

Likewise, application of sulphur increase plant growth through decreasing $\mathrm{pH}$ and increase cation exchange capacity (CEC) and releasing micronutrients as $\mathrm{Fe}$ and $\mathrm{Cu}$ which lead to an increment in photosynthesis. In addition sulphur plays an important role in plant metabolism. It had a main function in proteins or polypeptides formation. Participate to the formation of enzymes proteins and enzyme reactions as reported by Mengel and Kirkby (1978).

They added that sulphur is a constituent of CoA of the vitamins biotin and thiamine (sulphur is an essential element in thiazole ring which is a component of thiamine) which associated (Biotin) with $\mathrm{CO}_{2}$ fixation and decarboxylation reactions.

In this connection El-Tantawy and ElBeik (2009) found that application of $\mathrm{N}$ at a rate of $120 \mathrm{Kg} \mathrm{N} /$ fed., increased the vegetative growth and dry weight of onion plant significantly under the same region of this study and their results were due to application of $\mathrm{S}$ at a rate of $200 \mathrm{Kg} \mathrm{fed}^{-1}$., compared to control. In this connection, the increase in onion plant height, number of leaves/plant, length and diameter of leaves, leaf area and crop growth rate due to application of $\mathrm{N}$ were found by Brewster and Butler (1989), Kumar et al. (1998), and Islam et al.(1999). In addition Nasreen et al. (2003) found that the combination between $45 \mathrm{Kg} \mathrm{S}^{-1}$ and $120 \mathrm{Kg} \mathrm{N}^{-1}$ increased crop growth rate (CGR) and relative growth rate (RGR) of onion.

Additionally, Al-Fraihat (2009) found that the highest level of $\mathrm{N}\left(200 \mathrm{Kg} \mathrm{Nha}^{-1}\right)$ increased plant height and number of green leaves/plant as compared with control (100 $\left.\mathrm{Kg} \mathrm{Nha}^{-1}\right)$ he indicated that the increment in plant growth due to the addition of nitrogen to the high level that enhanced the number of leaves by its simulative effect on cell 
division and cell enlargement that in turn may increase number of leaves and leaf dimensions. He added that addition sulphur to onion plants increased plant height and number of green leaves up to $100 \mathrm{Kg} \mathrm{S}^{-1}$ without significant differences with $50 \mathrm{~kg} \mathrm{~S}$ $\mathrm{ha}^{-1}$. The lowest plant height was obtained with the interaction between $100 \mathrm{~kg} \mathrm{~N}+0.0$ $\mathrm{kg} \mathrm{S} \mathrm{ha}{ }^{-1}$, while, the highest plant height was with $200 \mathrm{~kg} \mathrm{~N} \mathrm{ha}^{-1}+50 \mathrm{~kg} \mathrm{~S} \mathrm{ha}^{-1}$.

Rizk Fatmaet al. (2012), Simon et al. (2014) and Gessesew et al. (2015) found that increment in plant growth was due to increase in $\mathrm{N}$ fertilization. On the other hand, Khan et al. (2002) found an increase in onion plant hight and number of leaves/ plant with application of moderate dose of $\mathrm{N}$ (100 kg ha ${ }^{-1}$.), while increasing the doses of nitrogen decreased onion plant height. Likewise, the increment due to addition of $\mathrm{N}$ and $\mathrm{S}$ may be attributed to the role of $\mathrm{N}$ in building up protoplasm and proteins, which induce cell division and meristematic activity resulting in more plant cells which increase plant growth (Devlin, 1979).

Many investigators reported that application of high rates of $\mathrm{N}$ and $\mathrm{S}$ resulted in higher plant height, maximum number of leaves, higher fresh and dry weight of onion plant (Mozumder et al., 2007; Rizk Fatma et al., 2012). They owed their results to application of sulphur which helps in the availability of other nutrients resulting in better growth and increased uptake of all the nutrients at higher levels of sulphur. Application of $\mathrm{S}$ at a moderate dose $(40 \mathrm{~kg}$ $\left.\mathrm{ha}^{-1}\right)$ increased leaf area compared to low $\left(0.0,20 \mathrm{~kg} \mathrm{~S} \mathrm{ha}^{-1}\right)$ or high levels of $\mathrm{S}(60$, $\left.80 \mathrm{~kg} \mathrm{~S} \mathrm{ha}{ }^{-1}\right)$ as showed by Mishu et al. (2013).

\section{Effect of treatments on yield and its component}

Results in Tables 6 and 7 illustrate that combination among $\mathrm{N}, \mathrm{K}$ and $\mathrm{S}$ as $150 \%$ $\mathrm{N}+75 \% \mathrm{~K}_{2} \mathrm{O}+200 \% \mathrm{~S}$ increased yields of $1^{\text {st }}$ and $2^{\text {nd }}$ grades in both seasons. Application of $150 \% \mathrm{~N}+150 \% \mathrm{~K}_{2} \mathrm{O}+200 \% \mathrm{~S}$ increased avg. bulb weight of $1^{\text {st }}, 2^{\text {nd }}, 3^{\text {rd }}$ and $4^{\text {th }}$, grade in both seasons. The increment in average bulb weight of $1^{\text {st }}$ and $2^{\text {nd }}$ grades led to the increment in yield of the same grades. The decrease of $3^{\text {rd }}$ and $4^{\text {th }}$ grades may be owe to the increment in yields of $1^{\text {st }}$ and $2^{\text {nd }}$ grades.

Concerning the marketable yield, the same data indicate that application of $150 \%$ $\mathrm{N}+75 \% \mathrm{~K}_{2} \mathrm{O}+200 \% \mathrm{~S}$ was the best treatment for increasing the marketable yield. This increment in marketable yield may be owe to the increase in the yields of $1^{\text {st }}$ and $2^{\text {nd }}$ grades which consists most marketable yield. Regarding decay and rotted yields, the data in Table 7 reveal that application of $75 \% \mathrm{~N}+150 \% \mathrm{~K}_{2} \mathrm{O}+100 \% \mathrm{~S}$ increased the rotted yield without significant differences with application of $150 \% \mathrm{~N}+$ $75 \% \mathrm{~K}_{2} \mathrm{O}+200 \% \mathrm{~S}$ in the $2^{\text {nd }}$ season. The same previous treatment $(75 \% \mathrm{~N}+150 \%$ $\mathrm{K}_{2} \mathrm{O}+100 \% \mathrm{~S}$ ) increased the decay yield in the $1^{\text {st }}$ season, but it increased in the $2^{\text {nd }}$ season with application of the highest rates of $\mathrm{N}, \mathrm{K}$ and $\mathrm{S}\left(150 \% \mathrm{~N}+150 \% \mathrm{~K}_{2} \mathrm{O}+\right.$ $200 \% \mathrm{~S}$ ).

So that, the total of unmarketable yield was increased with application of $75 \% \mathrm{~N}+$ $150 \% \mathrm{~K}_{2} \mathrm{O}+100 \% \mathrm{~S}$ in both seasons without significant differences with application of $150 \% \mathrm{~N}+150 \% \mathrm{~K}_{2} \mathrm{O}+200 \%$ $\mathrm{S}$ in the $2^{\text {nd }}$ season. This increment in unmarketable yield may be mainly owe to the increment in rotted and decay yield.

With regard to total yield, the same data in Table 7 show that fertilizing onion plants with $150 \% \mathrm{~N}+75 \% \mathrm{~K}_{2} \mathrm{O}+200 \% \mathrm{~S}$ was the superior treatment to increase the total yield in both seasons without significant differences with application of $150 \% \mathrm{~N}+$ $150 \% \mathrm{~K}_{2} \mathrm{O}+200 \% \mathrm{~S}$ and $75 \% \mathrm{~N}+150 \%$ $\mathrm{K}_{2} \mathrm{O}+100 \% \mathrm{~S}$ in the second season. The increment on total yield due to application of $150 \% \mathrm{~N}+75 \% \mathrm{~K}_{2} \mathrm{O}+200 \% \mathrm{~S}$ is mainly due to the increment in bulb weight, the yield of $1^{\text {st }}$ and $2^{\text {nd }}$ grades as well as the increase of yield $/ \mathrm{m}^{2}$. However, the increment 
Table (6): Effect of $N, K$ and $S$ combination treatments on yield of $1^{\text {st }}, 2^{\text {nd }}, 3^{\text {rd }}, 4^{\text {th }}$, and marketable yield of onion in 2014/ 2015 and 2015/ 2016 seasons.

\begin{tabular}{|c|c|c|c|c|c|c|c|c|c|c|c|c|c|}
\hline \multirow[t]{2}{*}{ Treatments } & \multicolumn{3}{|c|}{$1^{\text {st }}$ grade } & \multicolumn{4}{|c|}{$2^{\text {nd }}$ grade } & \multicolumn{2}{|c|}{$3^{\text {rd }}$ grade } & \multicolumn{2}{|r|}{$\begin{array}{c}4^{\text {th }} \\
\text { grade }\end{array}$} & \multicolumn{2}{|c|}{ Marketable yield } \\
\hline & $\begin{array}{c}\text { Bulb } \\
\text { avg. wt. } \\
\text { (g) }\end{array}$ & ton/ fed. & $\begin{array}{c}\text { As(\%) } \\
\text { of total }\end{array}$ & $\begin{array}{c}\text { Bulb } \\
\text { Avg. Wt. } \\
\text { (g) }\end{array}$ & $\begin{array}{l}\text { ton/ } \\
\text { fed. }\end{array}$ & $\begin{array}{c}\text { as } \% \text { of } \\
\text { total }\end{array}$ & $\begin{array}{c}1 \mathrm{st} \& 2^{\text {nd }} \\
\text { as }(\%)\end{array}$ & $\begin{array}{c}\text { Bulb avg. } \\
\text { wt. (g) }\end{array}$ & ton/fed & $\begin{array}{c}\text { Bulb avg. } \\
\text { wt. (g) }\end{array}$ & & d. & $\begin{array}{c}\text { as }(\%) \\
\text { of total }\end{array}$ \\
\hline & \multicolumn{13}{|c|}{ First season $(2014 / 2015)$} \\
\hline $100 \% \mathrm{~N}+100 \% \mathrm{~K}_{2} \mathrm{O}+100 \% \mathrm{~S}$ & $162.3 \mathrm{c}$ & $11.37 \mathrm{c}$ & $66.53 \mathrm{c}$ & $90.64 \mathrm{~b}$ & $3.494 \mathrm{~b}$ & $20.44 \mathrm{~b}$ & $86.97 \mathrm{~b}$ & $39.85 \mathrm{e}$ & $0.857 \mathrm{~g}$ & $0.000 \mathrm{~d}$ & $0.000 \mathrm{~g}$ & $15.54 \mathrm{~cd}$ & $91.70 \mathrm{~b}$ \\
\hline $75 \% \mathrm{~N}+75 \% \mathrm{~K}_{2} \mathrm{O}+100 \% \mathrm{~S}$ & $180.1 \mathrm{bc}$ & $10.79 \mathrm{c}$ & $68.16 \mathrm{bc}$ & $79.90 \mathrm{~cd}$ & $2.375 \mathrm{~d}$ & $15.00 \mathrm{~cd}$ & $83.16 \mathrm{~d}$ & $47.08 \mathrm{~cd}$ & $1.439 \mathrm{~b}$ & & $0.494 \mathrm{~d}$ & $14.60 \mathrm{de}$ & $2.22 \mathrm{~b}$ \\
\hline $75 \% \mathrm{~N}+75 \% \mathrm{~K}_{2} \mathrm{O}+200 \% \mathrm{~S}$ & $160.0 \mathrm{c}$ & $5.935 \mathrm{f}$ & $60.07 \mathrm{~d}$ & $73.10 \mathrm{~d}$ & $1.220 \mathrm{e}$ & $12.34 \mathrm{~d}$ & $72.41 \mathrm{e}$ & $42.90 \mathrm{de}$ & $1.116 \mathrm{f}$ & $16.38 \mathrm{c}$ & $0.582 \mathrm{c}$ & $8.271 \mathrm{~g}$ & $3.65 \mathrm{c}$ \\
\hline $75 \% \mathrm{~N}+150 \% \mathrm{~K}_{2} \mathrm{O}+100 \% \mathrm{~S}$ & $182.5 \mathrm{ab}$ & $6.795 \mathrm{e}$ & $46.38 \mathrm{f}$ & $97.51 \mathrm{ab}$ & $2.510 \mathrm{~d}$ & $17.13 \mathrm{bc}$ & $63.51 \mathrm{f}$ & $55.63 \mathrm{~b}$ & $1.222 \mathrm{de}$ & $20.81 \mathrm{~b}$ & $0.292 \mathrm{ef}$ & $10.53 \mathrm{f}$ & $1.82 \mathrm{~d}$ \\
\hline $75 \% \mathrm{~N}+150 \% \mathrm{~K}$ & $186.5 \mathrm{ab}$ & $9.126 \mathrm{~d}$ & $61.04 \mathrm{~d}$ & $92.43 \mathrm{ab}$ & $3.661 \mathrm{~b}$ & $24.48 \mathrm{a}$ & $85.52 \mathrm{bc}$ & $61.96 \mathrm{a}$ & $1.191 \mathrm{ef}$ & $28.96 \mathrm{a}$ & $0.847 \mathrm{a}$ & $13.98 \mathrm{e}$ & $3.44 \mathrm{~b}$ \\
\hline $150 \% \mathrm{~N}+75 \% \mathrm{~K}_{2} \mathrm{O}+100 \% \mathrm{~S}$ & $175.2 \mathrm{bc}$ & $8.927 d$ & $53.07 \mathrm{e}$ & $102.6 \mathrm{a}$ & $3.433 b$ & $20.41 \mathrm{~b}$ & $73.48 \mathrm{e}$ & $45.07 \mathrm{de}$ & $1.647 \mathrm{a}$ & $23.07 \mathrm{~b}$ & $0.760 \mathrm{~b}$ & $14.01 \mathrm{e}$ & $33.29 \mathrm{c}$ \\
\hline $150 \% \mathrm{~N}+75 \% \mathrm{~K}_{2} \mathrm{O}+200 \% \mathrm{~S}$ & $183.8 \mathrm{ab}$ & $14.90 \mathrm{a}$ & $66.36 \mathrm{~cd}$ & $94.69 \mathrm{ab}$ & $4.112 \mathrm{a}$ & $18.31 b c$ & $84.67 \mathrm{~cd}$ & $52.57 \mathrm{bc}$ & $1.335 \mathrm{c}$ & $30.06 \mathrm{a}$ & $0.547 \mathrm{~cd}$ & $20.35 \mathrm{a}$ & $90.60 \mathrm{~b}$ \\
\hline $150 \% \mathrm{~N}+150 \% \mathrm{~K}_{2} \mathrm{O}+100 \% \mathrm{~S}$ & $174.9 \mathrm{bc}$ & $12.79 \mathrm{~b}$ & $73.59 \mathrm{ab}$ & 88.04 bc & $2.741 \mathrm{c}$ & $15.77 \mathrm{bcd}$ & 89.36 a & $40.91 \mathrm{de}$ & $1.492 \mathrm{~b}$ & $22.00 \mathrm{~b}$ & $0.252 \mathrm{f}$ & $17.02 \mathrm{~b}$ & $97.88 \mathrm{a}$ \\
\hline \multirow[t]{2}{*}{$150 \% \mathrm{~N}+150 \% \mathrm{~K}_{2} \mathrm{O}+200 \% \mathrm{~S}$} & $211.9 \mathrm{a}$ & $12.66 \mathrm{~b}$ & $74.82 \mathrm{a}$ & $102.3 \mathrm{a}$ & $2.424 \mathrm{~d}$ & $14.32 \mathrm{~cd}$ & 89.14 a & $40.08 \mathrm{e}$ & $1.290 \mathrm{~cd}$ & $23.31 \mathrm{~b}$ & $0.311 \mathrm{e}$ & $16.38 \mathrm{bc}$ & $96.75 \mathrm{a}$ \\
\hline & \multicolumn{13}{|c|}{ Second season $(2015 / 2016)$} \\
\hline $100 \% \mathrm{~N}+100 \% \mathrm{~K}_{2} \mathrm{O}+100 \% \mathrm{~S}$ & $188.3 \mathrm{ab}$ & $12.94 \mathrm{~b}$ & $75.06 \mathrm{~d}$ & $78.41 \mathrm{c}$ & $2.241 \mathrm{a}$ & $13.01 \mathrm{~b}$ & $88.07 \mathrm{a}$ & $41.58 \mathrm{ab}$ & $0.130 \mathrm{a}$ & $0.000 \mathrm{~d}$ & $0.000 \mathrm{f}$ & $15.31 \mathrm{abc}$ & $38.76 \mathrm{c}$ \\
\hline $75 \% \mathrm{~N}+75 \% \mathrm{~K}_{2} \mathrm{O}+100 \% \mathrm{~S}$ & $175.3 \mathrm{ab}$ & $10.91 \mathrm{c}$ & $70.17 \mathrm{e}$ & $85.01 \mathrm{~b}$ & $2.140 \mathrm{a}$ & $13.76 \mathrm{a}$ & $83.93 \mathrm{c}$ & $43.00 \mathrm{ab}$ & $0.336 \mathrm{a}$ & $0.000 \mathrm{~d}$ & $0.000 \mathrm{f}$ & $13.39 \mathrm{de}$ & $86.11 \mathrm{~d}$ \\
\hline $75 \% \mathrm{~N}+75 \% \mathrm{~K}_{2} \mathrm{O}+200 \% \mathrm{~S}$ & $166.9 \mathrm{~b}$ & $10.27 \mathrm{c}$ & $69.74 \mathrm{e}$ & $75.79 c$ & $1.571 \mathrm{~b}$ & $10.67 \mathrm{c}$ & $80.41 \mathrm{~d}$ & & & $21.44 \mathrm{~b}$ & $0.033 \mathrm{~d}$ & & $83.71 \mathrm{e}$ \\
\hline $75 \% \mathrm{~N}+150 \% \mathrm{~K}_{2} \mathrm{O}+100 \% \mathrm{~S}$ & $173.0 \mathrm{ab}$ & $13.16 \mathrm{~b}$ & $73.32 \mathrm{~d}$ & $85.81 \mathrm{~b}$ & $1.329 \mathrm{c}$ & $7.404 \mathrm{f}$ & $80.72 \mathrm{~d}$ & $30.88 \mathrm{c}$ & $0.563 \mathrm{a}$ & $0.000 \mathrm{~d}$ & $0.000 \mathrm{f}$ & bed & $83.72 \mathrm{e}$ \\
\hline $75 \% \mathrm{~N}+150 \% \mathrm{~K}_{2} \mathrm{O}+200 \% \mathrm{~S}$ & $182.5 \mathrm{ab}$ & $12.54 \mathrm{~b}$ & $81.57 \mathrm{~b}$ & $65.81 \mathrm{~d}$ & $1.118 \mathrm{c}$ & $7.276 \mathrm{f}$ & $88.85 \mathrm{a}$ & $25.22 \mathrm{~d}$ & $0.283 \mathrm{a}$ & $0.000 \mathrm{~d}$ & $0.000 \mathrm{f}$ & 13.94 cde & $90.69 \mathrm{a}$ \\
\hline $150 \% \mathrm{~N}+75 \% \mathrm{~K}_{2} \mathrm{O}+100 \% \mathrm{~S}$ & $181.2 \mathrm{ab}$ & $14.94 \mathrm{a}$ & $84.27 \mathrm{a}$ & $65.34 \mathrm{~d}$ & $0.700 \mathrm{~d}$ & $3.951 \mathrm{~g}$ & $88.22 \mathrm{a}$ & $42.76 \mathrm{ab}$ & $0.466 \mathrm{a}$ & $22.45 b$ & $0.120 \mathrm{c}$ & $16.11 \mathrm{ab}$ & $90.94 \mathrm{a}$ \\
\hline $150 \% \mathrm{~N}+75 \% \mathrm{~K}_{2} \mathrm{O}+200 \% \mathrm{~S}$ & $183.5 \mathrm{ab}$ & $14.91 \mathrm{a}$ & $74.70 \mathrm{~d}$ & $89.99 \mathrm{ab}$ & $2.058 \mathrm{a}$ & $10.31 \mathrm{c}$ & $85.01 \mathrm{bc}$ & $45.00 \mathrm{a}$ & $0.193 \mathrm{a}$ & $15.00 \mathrm{c}$ & $0.019 \mathrm{e}$ & $17.16 \mathrm{a}$ & $85.99 \mathrm{~d}$ \\
\hline $150 \% \mathrm{~N}+150 \% \mathrm{~K}_{2} \mathrm{O}+100 \% \mathrm{~S}$ & $189.3 \mathrm{ab}$ & $13.60 \mathrm{~b}$ & $77.20 \mathrm{c}$ & $85.68 \mathrm{~b}$ & $1.689 \mathrm{~b}$ & $9.561 \mathrm{~d}$ & $86.76 \mathrm{ab}$ & $42.56 \mathrm{ab}$ & $0.496 \mathrm{a}$ & $21.83 \mathrm{~b}$ & $0.137 \mathrm{~b}$ & $15.79 \mathrm{abc}$ & $89.61 \mathrm{~b}$ \\
\hline $150 \% \mathrm{~N}+150 \% \mathrm{~K}_{2} \mathrm{O}+200 \% \mathrm{~S}$ & $192.2 \mathrm{ab}$ & $13.95 \mathrm{~b}$ & $73.03 \mathrm{~d}$ & $95.44 \mathrm{a}$ & $1.638 \mathrm{~b}$ & $8.571 \mathrm{e}$ & $81.60 \mathrm{~d}$ & $46.67 \mathrm{a}$ & $0.323 \mathrm{a}$ & $30.21 \mathrm{a}$ & $0.191 \mathrm{a}$ & $15.91 \mathrm{ab}$ & $83.29 \mathrm{e}$ \\
\hline
\end{tabular}

Values having the same alphabetical letter(s) did not significantly differ at 0.05 level of significance according to Duncan's multiple range test.

Table (7): Effect of $N, K$ and $S$ combination treatments on decay, rotted, unmarketable yield, total yield and bulb average weight of onion in 2014/2015 and 2015/ 2016 seasons.

\begin{tabular}{|c|c|c|c|c|c|c|c|c|}
\hline \multirow[t]{2}{*}{ Treatments } & \multirow[t]{2}{*}{ Decay } & \multicolumn{2}{|c|}{ Rooted } & \multicolumn{2}{|c|}{$\begin{array}{c}\text { Unmarketable } \\
\text { yield }\end{array}$} & \multicolumn{2}{|c|}{ Total yield } & \multirow{2}{*}{$\begin{array}{c}\text { Avreg.w } \\
\text { of bulb } \\
\text { (gm) }\end{array}$} \\
\hline & & n/fed. & $\begin{array}{l}\operatorname{As}(\%) \\
\text { of total }\end{array}$ & ton/ fed. & $\begin{array}{l}\text { as }(\%) \\
\text { of total }\end{array}$ & on/ fed. & $\mathrm{kg} / \mathrm{m}^{2}$ & \\
\hline \multicolumn{9}{|c|}{ First season (2014/2015) } \\
\hline $100 \% \mathrm{~N}+100 \% \mathrm{~K}_{2} \mathrm{O}+100 \% \mathrm{~S}$ & $1.377 \mathrm{~b}$ & $0.000 \mathrm{~d}$ & $0.000 \mathrm{c}$ & $1.377 \mathrm{e}$ & $8.050 \mathrm{c}$ & $17.09 \mathrm{bc}$ & $4.026 \mathrm{bc}$ & $128.9 \mathrm{bc}$ \\
\hline $75 \% \mathrm{~N}+75 \% \mathrm{~K}_{2} \mathrm{O}+100 \% \mathrm{~S}$ & $0.737 \mathrm{~d}$ & $0.000 \mathrm{~d}$ & $0.000 \mathrm{c}$ & $1.231 \mathrm{e}$ & $7.770 \mathrm{c}$ & $15.83 \mathrm{c}$ & $3.770 \mathrm{~cd}$ & $121.5 \mathrm{~cd}$ \\
\hline $75 \% \mathrm{~N}+75 \% \mathrm{~K}_{2} \mathrm{O}+200 \% \mathrm{~S}$ & $1.034 \mathrm{c}$ & $0.000 \mathrm{~d}$ & $0.000 \mathrm{c}$ & $1.616 \mathrm{~d}$ & $16.35 \mathrm{~b}$ & $9.890 \mathrm{~d}$ & $2.354 \mathrm{~d}$ & $70.63 \mathrm{f}$ \\
\hline $75 \% \mathrm{~N}+150 \% \mathrm{~K}_{2} \mathrm{O}+100 \% \mathrm{~S}$ & $2.445 \mathrm{a}$ & $1.394 \mathrm{a}$ & $9.510 \mathrm{a}$ & $4.130 \mathrm{a}$ & $28.19 \mathrm{a}$ & $14.66 \mathrm{c}$ & $3.490 \mathrm{~d}$ & $100.3 \mathrm{e}$ \\
\hline $75 \% \mathrm{~N}+150 \% \mathrm{~K}_{2} \mathrm{O}+200 \% \mathrm{~S}$ & $0.000 \mathrm{f}$ & $0.133 \mathrm{c}$ & $0.880 \mathrm{c}$ & $0.981 \mathrm{f}$ & $6.560 \mathrm{c}$ & $14.96 \mathrm{c}$ & $3.561 \mathrm{~d}$ & $110.8 \mathrm{de}$ \\
\hline $150 \% \mathrm{~N}+75 \% \mathrm{~K}_{2} \mathrm{O}+100 \% \mathrm{~S}$ & $1.287 \mathrm{~b}$ & $0.771 \mathrm{~b}$ & $4.580 \mathrm{~b}$ & $2.818 b$ & $16.75 \mathrm{~b}$ & $16.82 \mathrm{bc}$ & $4.004 \mathrm{bc}$ & $127.4 \mathrm{bcc}$ \\
\hline $150 \% \mathrm{~N}+75 \% \mathrm{~K}_{2} \mathrm{O}+200 \% \mathrm{~S}$ & $0.783 \mathrm{~d}$ & $0.778 \mathrm{~b}$ & $3.460 \mathrm{~b}$ & $2.110 \mathrm{c}$ & $9.390 \mathrm{c}$ & $22.46 \mathrm{a}$ & $5.347 \mathrm{a}$ & $158.4 \mathrm{a}$ \\
\hline $150 \% \mathrm{~N}+150 \% \mathrm{~K}_{2} \mathrm{O}+100 \% \mathrm{~S}$ & $0.116 \mathrm{e}$ & $0.000 \mathrm{~d}$ & $0.000 \mathrm{c}$ & $0.369 \mathrm{~h}$ & $2.120 \mathrm{~d}$ & $17.39 \mathrm{~b}$ & $4.140 \mathrm{~b}$ & $139.7 \mathrm{~b}$ \\
\hline $150 \% \mathrm{~N}+150 \% \mathrm{~K}_{2} \mathrm{O}+200 \% \mathrm{~S}$ & $0.151 \mathrm{e}$ & $0.088 \mathrm{c}$ & $0.520 \mathrm{c}$ & $0.550 \mathrm{~g}$ & $3.250 \mathrm{~d}$ & $16.95 \mathrm{bc}$ & $4.031 \mathrm{~b}$ & $168.7 \mathrm{a}$ \\
\hline \multicolumn{9}{|c|}{ Second season $(2015 / 2016)$} \\
\hline $100 \% \mathrm{~N}+100 \% \mathrm{~K}_{2} \mathrm{O}+100 \% \mathrm{~S}$ & $0.2390 \mathrm{~h}$ & $1.698 \mathrm{~b}$ & $9.854 \mathrm{~d}$ & $1.937 \mathrm{de}$ & $11.24 \mathrm{c}$ & $17.24 \mathrm{bcd}$ & bcd & $153.8 \mathrm{c}$ \\
\hline $75 \% \mathrm{~N}+75 \% \mathrm{~K}_{2} \mathrm{O}+100 \% \mathrm{~S}$ & 0.48 & $1.680 \mathrm{~b}$ & $10.80 \mathrm{c}$ & $\mathrm{cd}$ & $13.89 \mathrm{~b}$ & $15.55 \mathrm{cde}$ & 3.703 cde & $144.7 \mathrm{~d}$ \\
\hline $75 \% \mathrm{~N}+75 \% \mathrm{~K}_{2} \mathrm{O}+200 \% \mathrm{~S}$ & $0.6110 \mathrm{~b}$ & $1.755 \mathrm{~b}$ & $11.92 \mathrm{~b}$ & $2.399 \mathrm{c}$ & $16.29 \mathrm{a}$ & $14.73 \mathrm{e}$ & $3.507 \mathrm{e}$ & $134.8 \mathrm{e}$ \\
\hline $75 \% \mathrm{~N}+150 \% \mathrm{~K}_{2} \mathrm{O}+100 \% \mathrm{~S}$ & $0.3550 \mathrm{f}$ & $2.566 \mathrm{a}$ & $14.30 \mathrm{a}$ & $2.921 \mathrm{ab}$ & $16.28 \mathrm{a}$ & $17.97 \mathrm{ab}$ & $4.279 \mathrm{ab}$ & $151.3 \mathrm{c}$ \\
\hline $75 \% \mathrm{~N}+150 \% \mathrm{~K}_{2} \mathrm{O}+200 \% \mathrm{~S}$ & $0.2740 \mathrm{~g}$ & $1.157 \mathrm{~d}$ & 7.530 ef & $1.431 \mathrm{f}$ & $9.313 \mathrm{e}$ & $15.38 \mathrm{de}$ & $3.661 \mathrm{de}$ & $161.7 \mathrm{~b}$ \\
\hline $150 \% \mathrm{~N}+75 \% \mathrm{~K}_{2} \mathrm{O}+100 \% \mathrm{~S}$ & $0.1420 \mathrm{i}$ & $1.345 \mathrm{~cd}$ & $7.586 \mathrm{ef}$ & $1.607 \mathrm{ef}$ & $9.064 \mathrm{e}$ & $17.72 \mathrm{bc}$ & $4.219 \mathrm{bc}$ & $151.7 \mathrm{c}$ \\
\hline $150 \% \mathrm{~N}+75 \% \mathrm{~K}_{2} \mathrm{O}+200 \% \mathrm{~S}$ & $0.4430 \mathrm{e}$ & $2.336 \mathrm{a}$ & $11.70 \mathrm{~b}$ & $2.798 \mathrm{~b}$ & $14.01 \mathrm{~b}$ & $19.96 \mathrm{a}$ & $4.753 \mathrm{a}$ & $176.2 \mathrm{a}$ \\
\hline $150 \% \mathrm{~N}+150 \% \mathrm{~K}_{2} \mathrm{O}+100 \% \mathrm{~S}$ & $0.4520 \mathrm{~d}$ & $1.242 \mathrm{~cd}$ & $7.047 \mathrm{f}$ & $1.831 \mathrm{de}$ & $10.39 \mathrm{~d}$ & $17.62 \mathrm{bc}$ & $4.195 \mathrm{bc}$ & $135.7 \mathrm{e}$ \\
\hline $150 \% \mathrm{~N}+150 \% \mathrm{~K}_{2} \mathrm{O}+200 \% \mathrm{~S}$ & $1.484 \mathrm{a}$ & $1.529 \mathrm{bc}$ & $7.945 \mathrm{e}$ & $3.204 \mathrm{a}$ & $16.71 \mathrm{a}$ & $19.11 \mathrm{ab}$ & $4.551 \mathrm{ab}$ & $168.2 \mathrm{a}$ \\
\hline
\end{tabular}


in total yield duo to application of $75 \% \mathrm{~N}+$ $150 \% \mathrm{~K}_{2} \mathrm{O}+100 \% \mathrm{~S}$ in the $2^{\text {nd }}$ season may be owe to the increment in unmarketable yield.

Additionally, El-Tantawy and El-Beik (2009) found that the best combination treatment between $\mathrm{N}$ and $\mathrm{S}$ for increasing total, marketable yield and exportable yield of onion was the application of $120 \mathrm{Kg} \mathrm{N}+$ $200 \mathrm{Kg} \mathrm{S} \mathrm{fed}^{-1}$ plus foliar spray with $\mathrm{Cu}$ at a concentration of $30 \mathrm{ppm}$. Nasreen et al. (2003) found that the combination between $120 \mathrm{Kg} \mathrm{N}$ and $40 \mathrm{Kg} \mathrm{S} / \mathrm{ha}$ showed a synergistic effect on onion bulb yield. It could be noticed that application of $150 \% \mathrm{~N}$ $+75 \% \mathrm{~K}_{2} \mathrm{O}+200 \% \mathrm{~S}$ was the best treatment for increasing the total yield and its component compared to the recommendation treatment and other treatments.

The previous treatment recorded increases of relative total yield by $131.42 \%$ and $115.77 \%$ in $1^{\text {st }}$ and $2^{\text {nd }}$ seasons, respectively compared to control treatment (recommended dose); increment in marketable yield by $130.95 \%$ and $112.08 \%$ in $1^{\text {st }}$ and $2^{\text {nd }}$ seasons, respectively.

The increment in relative marketable yield due to application of $150 \% \mathrm{~N}+$ $75 \% \mathrm{~K}_{2} \mathrm{O}+200 \% \mathrm{~S}$ compared to the recommended dose may be owe to the increase in relative yield of both $1^{\text {st }}$ and $2^{\text {nd }}$ grades which increased by $131.04 \%$, $115.22 \%$ for the $1^{\text {st }}$ grade in both seasons, respectively, and by 127.89 and $111.77 \%$ for the sum of $1^{\text {st }}+2^{\text {nd }}$ grades in the $1^{\text {st }}$ and $2^{\text {nd }}$ seasons, respectively.

The increase of marketable yield and total yield may be attributed to the increments in plant growth, total fresh weight of plant, total dry weight of plant and higher content of photosynthetic pigments (Tables 2, 3, 4 and 5).

These results are coincide with these reported by El-Tantawy and El-Beik (2009) who found that the yield of $1^{\text {st }}$ grade of onion was increased with increasing $\mathrm{N}$ up to $120 \mathrm{Kg} \mathrm{Nfed} .^{-1}$, while the yield of $3^{\text {rd }}$ grade was decreased resulting in an increase in $1^{\text {st }}$ grade, increased the marketable yield, exportable yield and total yield.

They added that increments in yield may be attributed to the best vegetative growth and increase in the photosynthetic production which increased bulb size and bulb weight. Similar results were obtained by Baloch et al. (1991), Al-Moshileh (2002), Khan et al. (2002), Nasreen et al. (2003) and Aliyu et al. (2008).

Al-Fraihat (2009) found that marketable yield and total yield were increased with increasing the rates of $\mathrm{S}$ to $100 \mathrm{~kg} \mathrm{~S} / \mathrm{ha}$ and $\mathrm{N}$ to $200 \mathrm{~kg} \mathrm{Nha}{ }^{-1}$. It was reported that addition of $\mathrm{N}$ and sulpur may be attributed to the increment in plant growth due to of $\mathrm{N}$ that enhanced accelerating the phytosynthtace in storage organs of bulbs resulting in an increase in bulb weight, as well as to the role of $\mathrm{S}$ in protein and hormones formation, enzymatic actions, chlorophyll formation, synthesis of amino acids and vitamins which helps to have good vegetative growth leading to height yield.

High yield was observed with the high rates of $\mathrm{N}$ and sulphur this may be attributed to oxidation of $\mathrm{S}$ to $\mathrm{SO}_{4}^{-2}$ that increased with increasing rate of $\mathrm{N}$ up to $248 \mathrm{~kg} \mathrm{ha}^{-1}$ (Awad, Nemat et al., 2011) and the oxidation was rapid in a field soil with $\mathrm{pH} 8.0$ leading to an enhancement in nutrients availability and increase in plant growth as well as in yield.

Many researchers came to similar results that high rates of $\mathrm{S}$ increased onion yield (Mishu et al., 2013; Nasreen and ImamulHuq, 2005) and high $\mathrm{N}$ rates increased onion yield (Smriti et al., 2002; Mozumder et al., 2007), and that high $\mathrm{N}$ rates which may be owe to the high needs for onion yield where $\mathrm{N}$ can easily volatile and leached out of root zones (Brewster and Bulter, 1989; Marschner, 1995). 


\section{Pungency}

\section{Effect of treatments on onion pungency}

Concerning the effect of $\mathrm{N}, \mathrm{K}$ and $\mathrm{S}$ combinations on pungency. It was found from Fig. 1 that application of $100 \% \mathrm{~N}+$ $100 \% \mathrm{~K}_{2} \mathrm{O}+100 \% \mathrm{~S}$ (recommended dose) recorded the highest value of onion pungency with no significant differences with the next treatments $(75 \% \mathrm{~N}+75 \%$ $\mathrm{K}_{2} \mathrm{O}+100 \% \mathrm{~S}, 75 \% \mathrm{~N}+75 \% \mathrm{~K}_{2} \mathrm{O}+200 \%$ $\mathrm{S}, 75 \% \mathrm{~N}+150 \% \mathrm{~K}_{2} \mathrm{O}+100 \% \mathrm{~S}, 75 \% \mathrm{~N}+$ $150 \% \mathrm{~K}_{2} \mathrm{O}+200 \%$ S) (Fig.1), while the treatments that had high nitrogen contents it decreased the content of pungency specially application of $150 \% \mathrm{~N}+75 \% \mathrm{~K}_{2} \mathrm{O}+100 \%$ $\mathrm{S}$, which recorded the lowest value of pungency without significant differences with the treatments of $150 \% \mathrm{~N}+75 \% \mathrm{~K}_{2} \mathrm{O}$ $+200 \% \mathrm{~S}, 150 \% \mathrm{~N}+150 \% \mathrm{~K}_{2} \mathrm{O}+100 \% \mathrm{~S}$, $150 \% \mathrm{~N}+150 \% \mathrm{~K}_{2} \mathrm{O}+200 \% \mathrm{~S}$. Thes results are in agreement with Abd ElKader et al. (2007) who found that application of nitrogen increased pungency up to $100 \mathrm{~kg} \mathrm{Nfed}^{-1}$. and it decreased with high amount of $\mathrm{N}\left(120 \mathrm{~kg} \mathrm{Nfed}^{-1}\right)$.

A close relationship between pyrovic acid development and the sensory evaluation of pungency has been established (Smittle et al., 1979). Pungency has ben positively correlated with sulphur fertilization rates (Freeman and Mossadeghi, 1970), while Kil et al. (2006) demonstrated that the pungency levels were not positively correlated with soil sulphur nutrition levels. Therefore, choosing cultivars with low pungency, ideal growing environments and proper sulphur nutrition control, are key factors in producing sweet onion. In this respect, Lancaster and Boland (1990) stated that, sulphur fertility is of particular interest because the primary falvor compounds in onions are sulphur based.On the other hand, Paula et al. 2002) and Lee et al. (2009) found no increase in the pungency of onion with increasing $\mathrm{S}$ doses, this may be owe to pungency intensity is controlled by genetic and environmental factors with differences between cultivars which pungency does not increase with increasing $\mathrm{S}$ doses (Randle and Bussard, 1993; Randle, 1997; Mccallum et al., 2001).

Approximately $80 \%$ of variation in the level of pungency in onions is explained by genetic factors (Yoo et al., 2006 and Grangerio et al., 2008). Onion pungency depended on the amount of pyruvic acid produced after slicing and its genetic characteristics and variety (Lin et al., 1995).

An increase level of pyruvate with $\mathrm{N}$ application could be explained partly by greater synthesis and accumulation of sulphur containing amino acids that are precursors of flavor compounds and pyruvate (Randel, 2000) which represented the amount of enzymatically produced pyruvate with $\mathrm{N}$ fertilization.

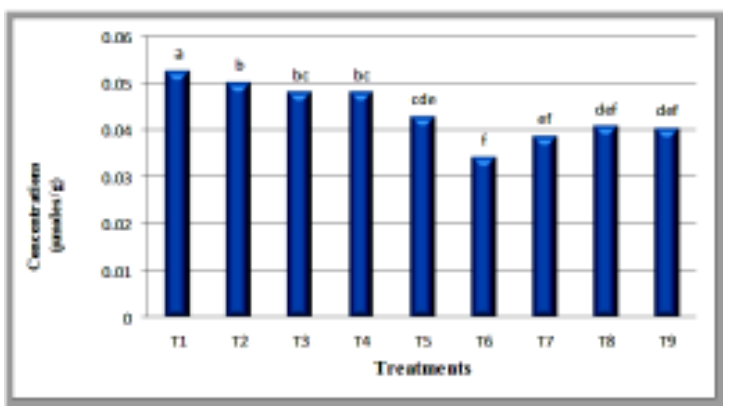

Fig (1): Effect of $N$, $K$ and $S$ combination treatments on onion pungency

$\mathrm{T}_{1}(100 \% \mathrm{~N}+100 \% \mathrm{~K}+100 \% \mathrm{~S}), \mathrm{T}_{2}(75 \% \mathrm{~N}+75 \% \mathrm{~K}+100 \% \mathrm{~S}), \mathrm{T}_{3}(75 \% \mathrm{~N}+75 \% \mathrm{~K}+200 \% \mathrm{~S}), \mathrm{T}_{4}(75 \% \mathrm{~N}+150 \%$ $\mathrm{K}+100 \% \mathrm{~S}), \mathrm{T}_{5}(75 \% \mathrm{~N}+150 \% \mathrm{~K}+200 \% \mathrm{~S}), \mathrm{T}_{6}(150 \% \mathrm{~N}+75 \% \mathrm{~K}+100 \% \mathrm{~S}), \mathrm{T}_{7}(150 \% \mathrm{~N}+75 \% \mathrm{~K}+200 \% \mathrm{~S}), \mathrm{T}_{8}$ $(150 \% \mathrm{~N}+150 \% \mathrm{~K}+100 \% \mathrm{~S}), \mathrm{T}_{9}(150 \% \mathrm{~N}+150 \% \mathrm{~K}+100 \% \mathrm{~S})$. 


\section{REFERENCES}

Abd El-Aal, F.S.; Shafeek, M.R.; Ahmed, A.A. and Shaheen, A.M. (2005). Response of growth and yield of onion plants to potassium fertilizer and humic acid. J. Agric. Sci., Mansoura Univ., 30 (1): 315-326.

Abd El-Kader, A.A.; Mohamedin, A.A.M. and Al-Kady, K.A. (2007). Effect of nitrogen and micronutrients on growth, yield, nutrient uptake and some biochemical properties of onion (Allium сера L.) plants under sandy soil. Egypt. J. App. Sci., 22 (2B): 767-778.

Ackley, W.B. (1964). Seasonal and diyrnal changes in the water content and water deficit of barclect bear leaves plant physical., 29: 445-448.

Al-Fraihat, A.H. (2009). Effect of different nitrogen and sulphur fertilizer levels on growth, yield and quality of onion (Allium cepa, L.) Jordan J. Agric. Sci., 5 (2):155-166.

Aliyu, U.; Dikko, A.U.; Magaji, M.D. and Singh, A. (2008). Nitrogen and nitra-row spacing effects on growth and yield of onion (Allium cepa L.). J. Plant Sci., 3 (2): 188-193.

Al-Moshileh, A.M. (2002). Effect of rate and time of nitrogen application on onion production in the central region of Saudi Arabia. J. King Saud Univ., 14 (1): 33-41.

Awad, N.M.; Abd El-Kader, A.A.; Attia, M. and Alva, A.K. (2011). Effects of nitrogen fertilization and soil inoculation of sulfur-oxidizing or nitrogen-fixing bacteria on onion Plant growth and yield. Int. J. Agron., 10 (6): 1-6.

Baloch, M.A.; Baloch, A.F.; Baloch, G.; Ansari, A.H. and Qayyum, S.M. (1991). Growth and yield response of onion to different nitrogen and potassium fertilizer combination levels. Sarhad J. Agric., 7: 63-66.
Behairy, A.G.; Asmaa, R.M.; Shafik, M.R.; Aisha, H.A. and Magda, M.H. (2015). Growth, yield and bulb quality of onion plants (Allium cepa L.) as affected by foliar and soil application of potassium. Middle East J. Agric. Res., 4 (1): 60-66.

Biru, F.N. (2015). Effect of spacing and nitrogen fertilizer on the yield and yield component of shallot (Allium ascalonicum L.). J. Biol., Agric. and Healthcare, 15 (11): 2224-3208.

Brewster, J.L. and Butler, H.A. (1989). Effects of nitrogen supply on bulb development in onion (Allium cepa L.). J. Exp. Bot., 40 (10): 1155-1162.

de Souza, G.L.F.; Filho, A.B.C.; Alberto de Tulio, F. and Nowaki, R.H.D. (2015). Effect of sulphur dose on the productivity and quality of onions. A. J. Crop. Sci., 9 (8):728-733.

Devlin, R.M. (1979). Plant physiology. Third Ed., Affiliated East West Press, New Delhi, Madras.

Duncan, D.B. (1955). Multiple range and Multiple F test. Biometrics, 11: 1- 42.

El-Bassiony, A.M. (2006). Effect of potassium fertilization on growth, yield and quality of onion plants. J. App. Sci. Res., 2 (10): 780-785.

El-Desuki, M.; Abdel-Mouty, M.M. and Aisha, H.A. (2006). Response of onion plants to additional dose ofpotassium application. J. App. Sci. Res., 2 (9): 592597.

El-Eweddy, E.A.; Beheiry, G.Gh.S. and Alaga, M.D. (2005). The effect of elemental sulfur and synthetic soil conditioners on some chemical properties and plant production of calcareous soils. Egypt. J. App. Sci., 20 (12): 734-747.

El-Galla, A.M.; Mostafa, M.A. and ElMaghraby, S.E. (1989). Influence of 
sulphur and saline irrigationwater on growth and elemental status of barley plant in calcareous soils. Egypt. J. Soil. Sci., 31: 443-445.

El-Tantawy, E.M. and El-Beik, A.K. (2009). Relationship between growth, yield and storability of onion (Allium сера L.) with fertilization of nitrogen, sulphur and copper under calcareous soil conditions. Res. J. Agric. and Biol. Sci., 5 (4): 361-371.

El-Sagan, M.A.M. and Abd El-Baset, A. (2015). Impact of magnetic on metal uptake, quality and productivity in onion crop. IOSR J. Agric. Vet. Sci., 8 (9): 43 50.

Freeman, G.G. and Mossadeghi, N. (1970). Effect of sulphat nutrition on flavor components of onion (Allium cepa L.). J. Sci. Food Agric., 21: 610 - 615.

Gessesew, W.S.; Woldetsadik, K. and Mohammed, W. (2015). Growth parameters of onion (Allium cepa L. var. сера) as affected by nitrogen fertilizer rates and intra-row spacing under irrigation in Gode, South-Eastern Ethiopia. Sci. Publishing Group, 4 (6): 2328-5648.

Grangeiro, L.C.; Souza, J.O.; Aroucha, E.M.M.; Nunes, G.H.S. and Santos, G.M. (2008). Caracteristicas qualitativas de genotipos de cebola. Cienc. Agrotec., 32 (4): 1087-1091.

Hetter, B. (1985). Utilization of sulphur for amendment on calcareous soil in Jordan. Proc. $2^{\text {nd }}$ Arab. Regional Conf. on Sulphur and Its Usages, Ryiadh, Saudi Arabia, 1:85-100.

Islam, M.A.; Shamsuddoha, A.T.M.; Bhuiyan, M.S.I. and Mirza, H. (2008). response of summer onion to potash and its application methods. Ame.-Eurasian J. Agron., 1 (1): 10-15.

Islam, M.K.; Awal, M.A.; Ahmed, S.U.; and Baten, M.A. (1999). Effect of different set sizes, spacings and nitrogen levels on the growth and bulb yield of onion. Pak. J. Biolo. Sci., 2 (4): 11431146.

Khafagi, M. and Abd El-Hadi, Y. (1990). Effect of sulphur application on salt distribution in a sodic calcareous soils. Egypt. J. Soil Sci., 30 (1): 199-212.

Khan, H.M.; Ghaffoor, I.A. and Waseem, K. (2002). Effect of various plant and different nitrogen levels on the growth and yield of onion (Allium cepa L.). Online J. Biol. Sci., 2 (8): 545-547.

Kil, S.Y.; Pike, L.; Crosby, K.; Jones, R. and Leskovar, D. (2006). Differences in onion pungency due to cultivars, growth environment, and bulb size. Sci. Hort., 110: 144-149.

Kołota, E.; Adamczewska-Sowińsk, K. and Uklańska-Pusz, C. (2013). Response of japanese bunching onion (Allium fistulosum L.) to nitrogen fertilization. Acta Sci. Pol., Hortorum Cultus, 12 (2): 51-61.

Kumar, H.; Singh, J.V.; Ajay, K.; Mahak, S.; Kumar, A. and Singh, M. (1998). Studies on the influence of nitrogen on growth and yield of onion cv. Panta Red. Indian J. Agric. Res., 32:88-92.

Lancaster, J.E. and Boland, M.J. (1990). Flavor Biochemistry, 33-72. In: H.D. Rabinowitch and J.L. Brewster (eds.) Onion and Allied Crops. 3CRC press, Boca Raton, Fla.

Lee, E.J.; Yoo, K.S.; Jifon, J. and Patil, B.S. (2009). Application of extra sulphur to high-sulphur soils dose not increase pungency and related compounds in short day onions. Sci. Hort. Amsterdam, 123 (12): 178-183.

Lin, M.W.; Waston, J.F. and Baggett, J.R. (1995). Inheritance of soluble solids and pyruvic acid content of bulb onions. J. Ame. Soc. Hort. Sci., 120 (10): 119122. 
Marschner, H. (1995). Mineral Nutrition of Higher Plants. $2^{\text {nd }}$ Ed., ACADEMIC PRESS, Harcourt, Brace and Company.

Mccallum, J.A.; Leite, D.; Pither-Joyce, M. and Havey, M.J. (2001). Expressed sequence markers for genetic analysis of bulb onion (Allium cepa L.) Theor. App. Genet., 103: 979-991.

Mengel, K. and Kirkby, E. (1978). Principles of Plant Nutrition International Potash Institute, P.O.ox, CH-3048 Worblaufen-Bern, Switzerland. 592pp.

Ministry of Agric., Egypt (2016). Statistical Year Book 2016.Agric. Static. Depart., Ref. No. 107.

Ministry of Agriculture and Soil Reclamation for Onion Exportation (1963). To control exported onion. Ministerial order No. 652.

Mishu, M.H.; Ahmed, F.; Rafi, M.Y.; Golam, F. and Latif, M.A. (2013). Effect of sulphur on growth, yield and yield attributes in onion (Allium cepa L.). Aust. J. Crop. Sci., 7 (9): 1416-1422.

Mozumder, S.N.; Moniruzzaman, M. and Halim, G.M.A. (2007). Effect of N, K and $\mathrm{S}$ on the yield and storability of transplanted onion (Allium cepa L.) in the hilly region. J. Agric. Rural. Dev., 5 (1\&2): 58-63.

Nasreen, S. and ImamulHuq, S.M. (2005). Effect of sulphur fertilization on yield, sulphur content and uptake by onion. Indin. J. Agric. Res., 39 (2):122-127.

Nasreen, S.; ImamulHaque, S.M. and Alta Hossain, M. (2003). Sulphur Effect on growth responses and yield of onion. Asian. J. Plant Sci., 2 (12): 897-902.

Paula, M.B.; Padua, J.G., Fontes, P.C.R. and Bertoni, J.C. (2002). Produtividade, qualidade de bulbos de cebola e teores de nutrients na planta e no solo influeniados por fonts de potassio e doses de gesso. Rev. Ceres., 43 (283): 231-244.
Randle, W.M. (1997). Onion flavor chemistry and factors influencing flavor intensity. ACS Sym Ser., 660: 41-42.

Randle, W.M. (2000). Increasing nitrogen concentration in hydroponic solutions affects onion flavor and bulb quality. J. Ame. Soc. Hort., 125: 245-259.

Randle, W.M. and Bussard, M.L. (1993). Pungency and sugars of short-day onions as affected by sulfur nutrition. J. Ame. Soc. Hort. Sci., 118:766-770.

Reddy, T.Y. and Reddi, G.H.S. (2002). Principles of Agronomy. Kalyani pulishers, $3^{\text {rd }}$ Ed., 526.

Rizk, F.A.; Shaheen, A.M., Abd ElSamad, E.H. and Swana, O.M. (2012). Effect of different nitrogen plus phosphorus and sulphur fertilizer levels on growth yield and quality of onion (Allium cepa L.) J. App. Sci. Res., 8 (7): 3353-3361.

Schwimmer, S. and Weston, W.J. (1961). Enzymatic development of pyruvic acid in onion as a measure of pungency. J. Agric. Food Chem., 9 (4): 301-304.

Shafeek, M.R.; Nagwa, M.K.; Hassan, S.; Singer, M. and El-Greadly, N.H.M. (2013). Effect of potassium fertilizer and foliar spraying with Etherel on plant development, yield and bulb quality of onion plants (Allium cepa L). J. Appl. Sci. Res., 9 (2): 1140-1146.

Siddiquee, M.S.H.; Rahim, M.A. and Mohiuddin, K.M. (2008). Effects of potassium on the growth and yield of two summer onion varieties. J. Agrofor. Environ., 2(1): 1-6.

Simon, T.; Tora, M.; Shumbulo, A. and Urkato, S. (2014). The effect of variety, nitrogen and phousphorous fertilization on growth and bulb yield of onion (Allium cepa L.) at Wolaita Southern Ethiopia. J. Biol., Agric. and Healthcare, 4 (11): 2224-3208. 
Smittle, D.A.; Hayers, M.J. and Diikens, W.L. (1979). Quality evaluation of onion. Georgia Agric. Expt. Sta. Res. Rpt., 336.

Smriti, S.; Kumar, R. and Singh, S.K. (2002). Effect of sulphur and boron nutrition on growth, yield and quality of onion (Allium cepa L.) J. Appl. Biol., 12 (1/2): 40-46.

Snedecor, G.W. and Cochran, W.G. (1980). Statistical Methods $7^{\text {th }}$ Ed. Iowa State Univ., Press. Ames. Iowa, USA.

Verma, D. and Singh, H. (2012). Response of varying levels of potassium and sulphur on yield and uptake of nutrients by onion. Ann. Plant Soil Res., 14 (2): 143-146.

Wettestein, D. (1957). Chlorophyll- Lethal und der Submicroscopiche Fromwechsel der Plastiden. Exptl. Cell Reso., 12: 427500.

Yoo, K.S.; Pike, L.; Crosby, K.; Jones, R. and Leskovar, D. (2006). Differences in onion pungency due to cultivars, growth environment, and bulb sizes. Sci. Hort. Amsterdam., 110: 144-149. 


\section{تأثير التذاخل بين النيتروجين، والبوتاسيوم، والكبريت على النمو والمحصول فى البصل

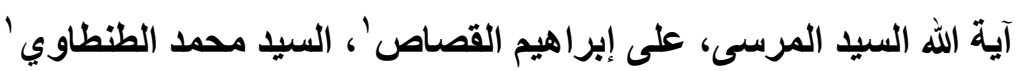

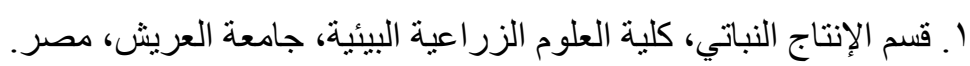

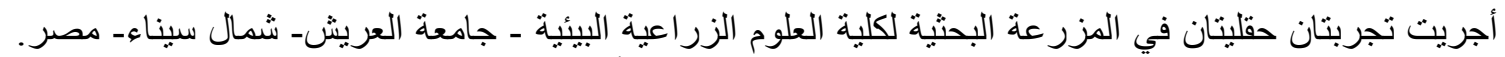

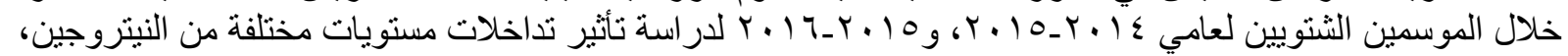

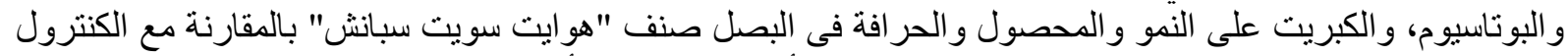

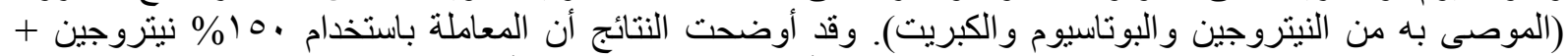

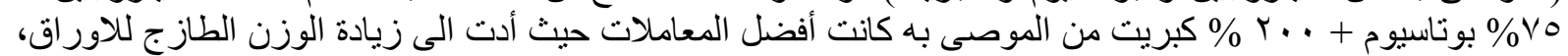

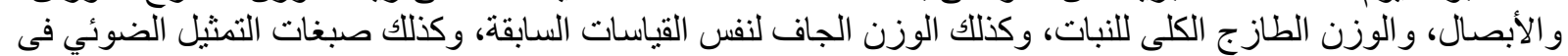

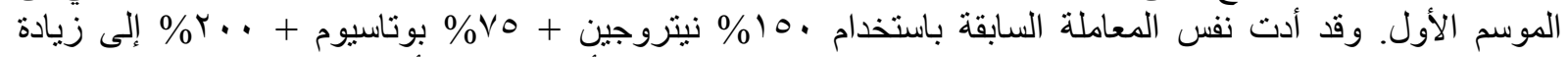

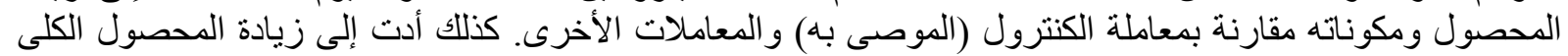

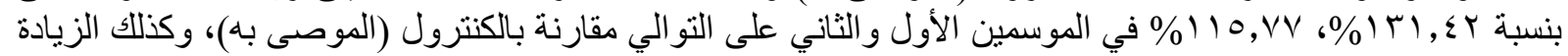

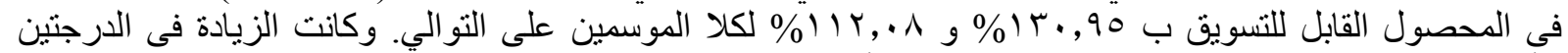

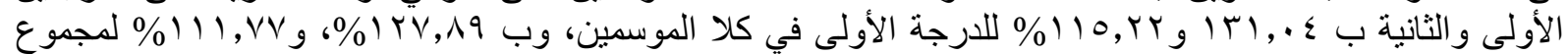

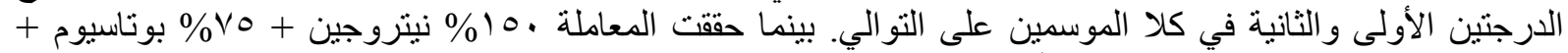

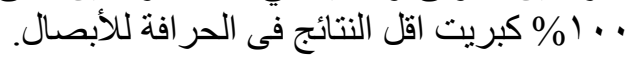

الكلمات الاسترشادية: البصل، و هو ايت سويت سبانش، و النيتروجين، و البوتاسيوم، و الكبريت، و المحصول، والحر افة. 